Article

\title{
Unraveling the Phylogenomic Relationships of the Most Diverse African Palm Genus Raphia (Calamoideae, Arecaceae)
}

\author{
Andrew J. Helmstetter ${ }^{1,+}{ }^{\circledR}$, Suzanne Mogue Kamga ${ }^{2}$, Kevin Bethune ${ }^{1}$, Thea Lautenschläger ${ }^{3}(\mathbb{D}$, \\ Alexander Zizka ${ }^{4}\left(\mathbb{D}\right.$, Christine D. Bacon ${ }^{5,6}{ }^{(\mathbb{D}}$, Jan J. Wieringa ${ }^{7} \mathbb{(}$, Fred Stauffer ${ }^{8}(\mathbb{D}$, \\ Alexandre Antonelli $5,6,9$ (1) and Bonaventure Sonké ${ }^{2}$ and Thomas L. P. Couvreur ${ }^{1, *(1)}$ \\ 1 IRD, DIADE, University Montpellier, 34394 Montpellier, France; andrew.j.helmstetter@gmail.com (A.J.H.); \\ kevin.bethune@hotmail.com (K.B.) \\ 2 Laboratoire de Botanique systématique et d'Ecologie, Department of Biological Sciences, \\ University of Yaoundé I, Higher Teacher Training College, Yaoundé B.P. 047, Cameroon; \\ mogueblue@yahoo.com (S.M.K.); bsonke_1999@yahoo.com (B.S.) \\ 3 Institute of Botany, Department of Biology, Faculty of Science, Technische Universität Dresden, \\ 01062 Dresden, Germany; thea.lautenschlaeger@tu-dresden.de \\ 4 German Center for Integrative Biodiversity Research (iDiv) Halle-Leipzig-Jena, 04103 Leipzig, Germany; \\ alexander.zizka@idiv.de \\ 5 epartment of Biological and Environmental Sciences and Gothenburg Global Biodiversity Centre, University \\ of Gothenburg, 40530 Gothenburg, Sweden; christine.bacon@bioenv.gu.se (C.D.B.); \\ a.antonelli@kew.org (A.A.) \\ 6 Gothenburg Global Biodiversity Centre, Box 461, SE 40530 Goteborg, Sweden \\ 7 Naturalis Biodiversity Center, Darwinweg 2, 2333 CR Leiden, The Netherlands; jan.wieringa@naturalis.nl \\ 8 Department of Botany and Plant Biology, Conservatory and Botanical Garden of the City of Geneva, \\ University of Geneva, 1205 Geneva, Switzerland; Fred.Stauffer@ville-ge.ch \\ 9 Royal Botanic Gardens, Kew, Richmond, Surrey TW9 3AE, UK \\ * Correspondence: thomas.couvreur@ird.fr \\ $\dagger$ Current address: FRB-Cesab, Institut Bouisson Bertrand, 5, rue de l'Ecole de médecine, \\ 34000 Montpellier, France.
}

Received: 15 March 2020; Accepted: 8 April 2020; Published: 23 April 2020

check for updates

\begin{abstract}
Palms are conspicuous floristic elements across the tropics. In continental Africa, even though there are less than 70 documented species, they are omnipresent across the tropical landscape. The genus Raphia has 20 accepted species in Africa and one species endemic to the Neotropics. It is the most economically important genus of African palms with most of its species producing food and construction material. Raphia is divided into five sections based on inflorescence morphology. Nevertheless, the taxonomy of Raphia is problematic with no intra-generic phylogenetic study available. We present a phylogenetic study of the genus using a targeted exon capture approach sequencing of 56 individuals representing 18 out of the 21 species. Our results recovered five well supported clades within the genus. Three sections correspond to those based on inflorescence morphology. R. regalis is strongly supported as sister to all other Raphia species and is placed into a newly described section: Erectae. Overall, morphological based identifications agreed well with our phylogenetic analyses, with 12 species recovered as monophyletic based on our sampling. Species delimitation analyses recovered 17 or 23 species depending on the confidence level used. Species delimitation is especially problematic in the Raphiate and Temulentae sections. In addition, our clustering analysis using SNP data suggested that individual clusters matched geographic distribution. The Neotropical species $R$. taedigera is supported as a distinct species, rejecting the hypothesis of a recent introduction into South America. Our analyses support the hypothesis that the Raphia individuals from Madagascar are potentially a distinct species different from the widely distributed $R$. farinifera. In conclusion, our results support the infra generic
\end{abstract}


classification of Raphia based on inflorescence morphology, which is shown to be phylogenetically useful. Classification and species delimitation within sections remains problematic even with our phylogenomic approach. Certain widely distributed species could potentially contain cryptic species. More in-depth studies should be undertaken using morphometrics, increased sampling, and more variable markers. Our study provides a robust phylogenomic framework that enables further investigation on the biogeographic history, morphological evolution, and other eco-evolutionary aspects of this charismatic, socially, and economically important palm genus.

Keywords: Africa; exons; Madagascar; rain forests; phylogenomics; Raphia; sequence capture

\section{Introduction}

Palms are iconic floristic elements across the tropics both in terms of diversity and the natural resources they provide, playing important roles for the welfare of rural and urban people at equatorial latitudes. Worldwide, there are an estimated 2500 palm species [1], mainly occurring in tropical rain forests. Africa, however, harbors less than 70 species (excluding Madagascar) [2,3], a pattern that contrasts strongly with the Neotropics or South East Asia, which contain 800 and 1200 species, respectively $[1,4,5]$. Despite this low diversity, palms are omnipresent across the African landscape, particularly in the tropical rain forests of the continent $[2,6]$.

Among African palms, the genus Raphia (subfamily Calamoideae, tribe Raphiaeae) is the most species rich, with 21 species described to date [2,7]. Of these, one, $R$. taedigera Mart., is endemic to the Neotropics, with a disjunct distribution in Brazil and central America. The presence of this species in the Neotropics was suggested as either pre-Colombian and natural (biogeographic long distance dispersal/vicariance [8,9]) or as recently naturalized by Africans during the slave trade some 400 years ago $[6,10,11]$. Raphia species mainly occur in tropical rain forests, most often in swampy or periodically inundated areas where they can dominate the vegetation, producing dense monospecific stands (known as "Raphiales" in French). A few species, however, have adapted to drier conditions restricted to river systems in the Sahel or southern Africa.

Raphia is one of the most economically important genus of African palms across tropical African communities. One recent study documented over 100 different uses across the genus, with the most important ones being extraction of palm wine, grubs and construction material [12,13]. Exploitation of its species in the wild also represents an important source of income for populations across tropical Africa, especially for low-income households $[12,14,15]$. In addition, Raphia species play vital ecological roles in wet land ecosystems [16] where they dominate the landscape, such as in peatlands of the Congo Basin where they are highly abundant [17]. Raphia dominated swamps are also important ecosystems for the protection for critically endangered animals, such as lowland gorillas because such areas are hard to access or to bring into cultivation (e.g., [18]).

Raphia species are massive palms with very long pinnate leaves. One species holds the record for the longest measured leaf in angiosperms, reaching up to 26 meters ( $R$. regalis). The stipe is generally above-ground and is solitary or clustered, while three species have very short (R. palma-pinus (Gaertn.) Hutch. and R. vinifera P. Beauv.) or subterranean (acaulescent) ( $R$. regalis Becc.) stipes. When present, the stipe can be covered by old leaf sheath remains or a dense network of fibers (decomposed leaf sheaths), which can be curly or straight, an important character to identify species (e.g., $[19,20])$. Raphia species are monoecious, with male and female flowers on the same individual and are hapaxanthic, meaning that individual stipes die after a single flowering event [1]. The inflorescence structure is relatively simple and branched to two orders [1]. The first and second order branches, or rachillae, are referred to as the "partial inflorescence" [21]. The shape and overall morphology of these partial inflorescences are one of the most important taxonomic characters for species identification and were used to define the different sections within the genus $[20,21]$. 
Despite its importance, Raphia remains one of the least understood palm genera in terms of taxonomy and phylogenetic relationships $[1,20]$. This is mainly due to their massive size, making them difficult to collect for non-specialists, which leads to few informative herbarium specimens or specimens that are incomplete or fragmentary and hence uninformative for taxonomy. Several attempts have been undertaken to tackle the taxonomy of the genus, beginning in the early 1900s with the first complete monograph of the genus [22]. This was followed by more regional attempts through the last century $[23,24]$. The last major revision of the genus was undertaken by Otedoh [21], who placed species into five different sections based on the structure of the partial inflorescence: Moniliformes (including the subsection Erectae), Temulentae, Raphiate, Flabellatae, and Obclavatae.

The six species within the Moniliformes section are characterized by thin and easily breakable rachillae when fresh (Figure 1B). Otedoh [21] also created a subsection, Erectae, where he placed two species in which the inflorescences are defined as erect (R. australis Oberm. and Strey, R. regalis) (Figure 1G,O). The Temulentae section has robust and tightly appressed rachillae. The partial inflorescences are racquet-shaped with the apical second order rachillae shorter than the basal ones (Figure 1E). This section contains three (possibly four) species, including one of the most widespread and important species R. hookeri G. Mann \& H. Wendl. With seven species, the Raphiate section is the most complex group of the genus. Several species in this section are only known from a few collections or just the type. This section is characterized by species having second order rachillae that are robust (thick) but loosely disposed between them (Figure 1D). The inflorescence within this section can be erect, semi-erect, or drooping (Figure 1I). The Flabellatae section contains two species with very characteristic partial inflorescence structures. The second order rachillae are tightly packed in a single plane being racket-shaped in appearance (Figure 1F). The inflorescence also has very conspicuous bracts that cover completely or partially the partial inflorescences (Figure 1O). Finally, the Obclavatae section contains one species (R. sudanica A. Chev.) with distinct club-shaped and compact partial inflorescences with large bracts covering too (Figure 1C).

To date, no in depth morphological or molecular phylogenetic study of Raphia has been undertaken. The most recent phylogenetic analysis of the Calamoideae subfamily included a single species and individual of Raphia, namely R. farinifera (Gaertn.) Hylander sequenced for the ribosomal region ITS and the plastid region rps16 [25]. The main objective of this study was to generate a densely sampled phylogenetic tree of the genus and test the validity of the taxonomic sections of Otedoh [21]. In particular, we tested if the partial inflorescence structure has a phylogenetic signal and is useful for Raphia species classification. In addition, by sampling several individuals per morphologically identified species, we also tested species delimitation and monophyly. In order to achieve these objectives, we sequenced more than 150 palm specific nuclear markers across 56 Raphia accessions. We used a species delimitation approach to define species limits and generated SNP data to study at fine-scale genetic relationships in identified species complexes. 
A

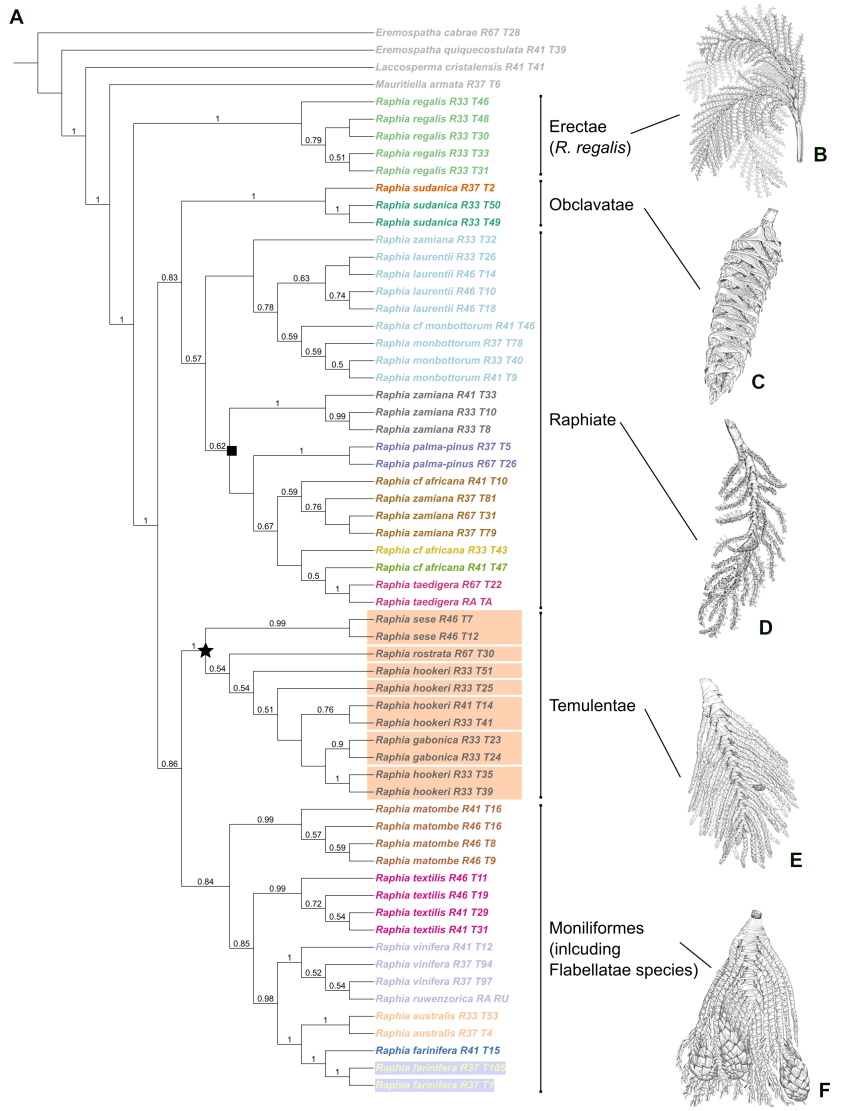

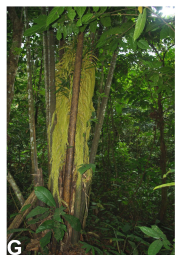
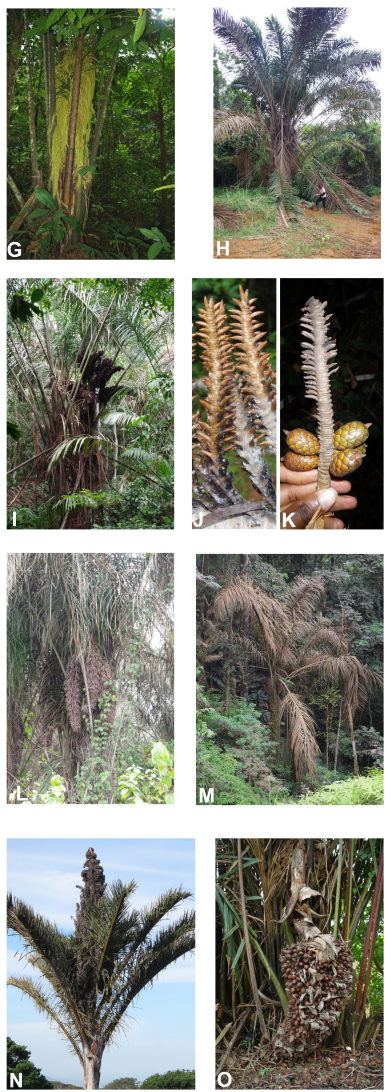

Figure 1. (A) Cladogram of the genus Raphia inferred using 85 gene trees and ASTRAL. Values of local posterior probabilities (LPP) equal or above 0.5 are shown above the branches. Branch lengths are represented in Figure A2. Individuals are color coded based on the hypothesis of species delimitation inferred using SODA with $\alpha=0.01$. For a single clade, the Temulentae section marked with a black star and referred to as the "hookeri" complex in the main text, varied between the two values of $\alpha$ used here. The orange boxes represent the species limits using SODA with a more stringent value of $\alpha=0.005$. The black square shows the "zamiana" complex clade. Tip names contain the species name as well as the sequencing ID. (B) $R$. regalis partial inflorescence representing the Erectae section (described here, see discussion). (C) R. sudanica inflorescence, representing the Obclavatae section. (D) R. palma-pinus inflorescence, representing the Raphiate section. (E) R. hookeri inflorescence, representing the Temulentae section. (F) R. farinifera inflorescence, representing the Moniliformes (and ex Flabellatae) section. (G) R. regalis, note the acaulescent habitat and inflorescences subtended by the leaves (Couvreur 398, Cameroon). (H) R. zamiana (Mogue Kamga 17, Gabon). (I) R. monbuttorum (Couvreur 1212, Cameroon), notice the semi-erect inflorescences. (J) detail of $R$. monbuttorum rachillae (Couvreur 1212, Cameroon). (K) detail of R. laurentii rachillae (Mogue Kamga 39, Democratic Republic of Congo). (L) R. hookeri (no voucher, Cameroon). (M) R. gabonica (Mogue Kamga 22, Gabon). (N) R. australis (no voucher, South Africa, Kirstenbosch Botanic Garden). (O) Inflorescence of $R$. vinifera (Couvreur 638, Cameroon). (B-F) line drawings by Mary Grierson reproduced with permission from [23] and Royal Botanic Gardens, Kew (U.K.); Photos (G-J), (L-O) T.L.P. Couvreur; Photo (K) S. Mogue Kamga.

\section{Results}

\subsection{DNA Sequencing}

We sequenced 56 individuals representing 18 species or $87.5 \%$ of the species diversity within the genus. A total of 15.4 million reads were generated and mapped to the reference exons belonging to 176 genes of the Heyduk et al. [26] baiting kit. Across all Raphia and outgroup individuals, the average coverage depth was 139.6x. We identified 102 genes for which $75 \%$ of the exon length was 
recovered in at least $25 \%$ of individuals. Twenty loci were flagged by Hybpiper as paralogs because multiple assembled contigs matched a single reference locus. Of these 20, those that occurred in the $75 / 25$ set were removed, resulting in a final dataset of 85 supercontigs equaling $162 \mathrm{~kb}$ of sequence data. Our SNP calling approach applied filters on mapping quality $(>40 \%)$ depth $(>25)$, quality by depth $(>2)$, minimum depth across individuals $(>10)$ minor allele frequency $(>0.01)$, and we excluded monomorphic sites. This ultimately yielded 915 and 1627 high-quality, biallelic SNPs for the $R$. hookeri and R. zamiana species complexes, respectively (see below). The fastq (R1 and R2) sequences for all individuals are available in Genbank's Sequence Read Archive (SRA) under Bioproject number PRJNA615688 (http:/ / www.ncbi.nlm.nih.gov/bioproject/615688).

\subsection{Evolutionary History of Raphia}

We generated two phylogenetic hypotheses for Raphia using two distinct methods. The first analysis was conducted based on a gene-tree coalescent approach using ASTRAL, while the second inferred phylogenetic relationships were based on a concatenated approach using IQ-TREE.

Support varied throughout the Raphia ASTRAL tree-About $50 \%$ of branches had a local posterior probability (LPP) above 75\% (Figure 1A). Major clades were well supported (LPP > 80\%) while relationships towards the tips of the tree generally had lower support. The final normalized quartet score, the proportion of quartet trees that agree with the species tree, was $65 \%$, indicating that there is gene tree conflict in the genus.

The IQ-TREE concatenated approach (see Figure A1 in Appendix B) had increased bootstrap support compared to ASTRAL. More than $88 \%$ of branches had bootstrap support greater than $75 \%$. The best partitioning scheme put the 85 loci into 20 different partitions. Major clades were again well-supported in this tree (bootstrap $>80 \%$ ).

Our phylogenetic analyses recovered five well supported clades. Three clades matched the sections as defined by Otedoh [21]. Raphia regalis was always inferred with strong support as sister to the rest of the genus independent of the inference method (Figures 1 and A1). When comparing the two phylogenetic approaches, we identified a topological difference in the phylogenetic placement of the section Temulentae, the species R. matombe, and the Moniliformes and Flabellatae sections (Figure 2). In the IQ-TREE analyses, we recovered weak support for the Temulentae as sister to all Raphia (except $R$. regalis) (Figure 2A) while the ASTRAL analysis indicates with higher support that Temulentae is sister to a clade containing R. matombe, Moniliformes and Flabellatae (Figure 2B).

A

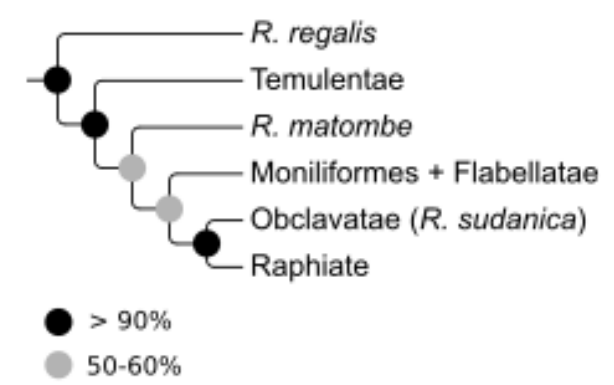

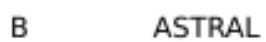

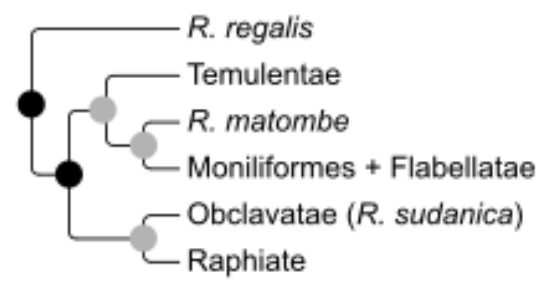

$=1.00$

$0.80-0.86$

Figure 2. Major incongruences between the (A) concatenation (IQ-TREE) and (B) gene tree (ASTRAL) phylogenetic approaches. Both trees have been modified to show the relationships among major Raphia clades. Support values are indicated on the nodes as either (a) bootstrap or (b) local posterior probability.

The relationships between species in the Raphiate section are weakly to moderately supported in both analyses (Figures 1 and A1). Nevertheless, we do recover monophyletic groups in some species consistent with prior morphological identifications. This is the case for individuals of R. laurentii and R. monbuttorum, which despite low support are monophyletic. Furthermore, both of these species are recovered as sister, with moderate to high support. However, our species delimitation 
analysis suggested that individuals identified under both species are conspecific (Figure 1A). Support is generally higher in the ASTRAL tree, even when taking into account different gene histories, so we suggest that the ASTRAL tree represents a more accurate reconstruction of the phylogeny of Raphia (Figure 2B) so we will principally refer to the relationships in this tree from now on.

\subsection{Species Delimitation}

Our species delimitation approach yielded between $17(\alpha=0.005)$ and $23(\alpha=0.01)$ species (Figure 1). Higher values of $\alpha$ split a clade of closely related individuals (marked with a star in Figure 1), predominantly belonging to $R$. hookeri, into seven different species. Generally, our species delimitation results corresponded well with our field identifications and using available floras (e.g., [19,20]). In some cases, we found that SODA split individuals belonging a priori to a single species into multiple species-for example, R. farinifera and R. sudanica (Figure 1). Conversely, individuals assigned to different species such as R. laurentii and R. monbuttorum were classified as the same species according to SODA delimitation independent of $\alpha$ values. In general, the support among different species as delimited by SODA was high (Figure 1).

\subsection{Fine Scale Structure in Two Species-Complexes}

To further explore genetic structure among our two main species complex, namely the "zamiana" and "hookeri" complexes (marked with a black square and a black star in Figure 1, respectively), we used SNPs extracted from the sequence data to look at the variation among individuals. The "hookeri" complex showed little evidence of clustering, with most individuals evenly spread out on the first two principal component (PCA) axes (Figure 3a). We observed two major groups of $>8$ individuals in the "zamiana" complex along PCA1 (Figure 3b), separating all of the R. laurentii and R. monbuttorum from the rest of the individuals. The first two PCAs in both analyses explained $7-10 \%$ of the variance in the dataset. This is a still less than a quarter of the total variance in each case, but this may be expected from our relatively complex dataset of almost 100 genes with independent histories. In general, our SNP data support SODA species delimitation as the assigned species grouped together along one or both of the first two PCAs in most cases (Figure 3a,b). Finally, our SNP data revealed that individuals within the "hookeri" complex clustered into four major groups (Figure 3a,c): the single individual from Togo; individuals from western Cameroon; individuals from East Cameroon and individuals from Gabon.

The plotting of these complexes on maps of the sampling region revealed that the delimited species clustered geographically (Figure 3c,d). In the "hookeri" complex, the R. sese individuals were sampled at a great distance from each other and $R$. gabonica falls in the middle of the $R$. hookeri distribution range. Likewise, in the "zamiana" complex, R. laurentii and R. monbuttorum are widespread, overlapping with other taxa. Many of the delimited species co-occur or are adjacent to one another in Cameroon. 


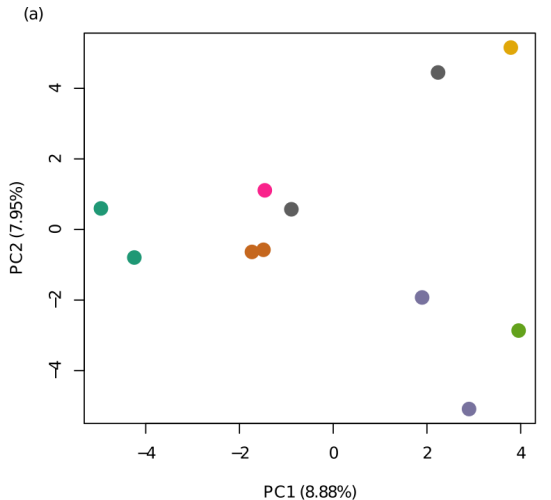

(c)

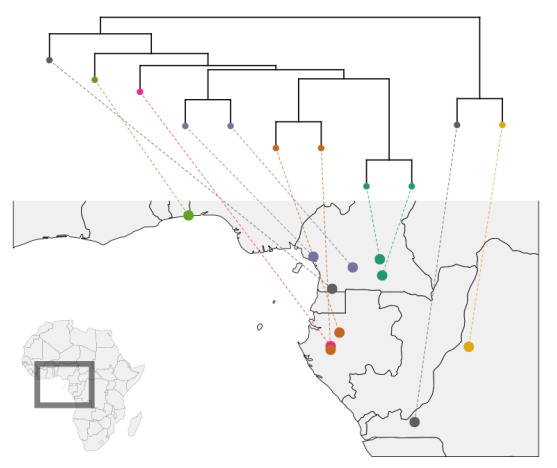

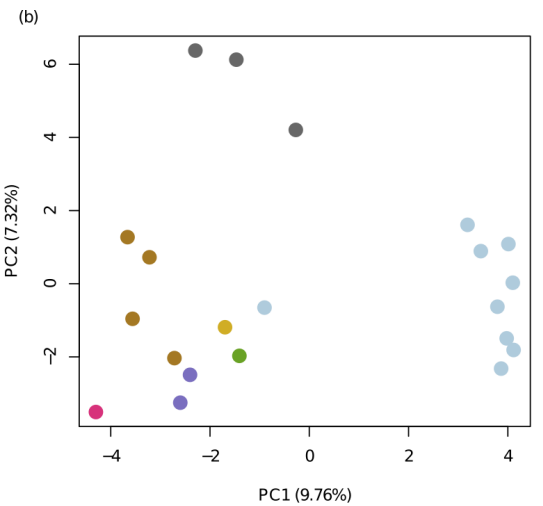

(d)

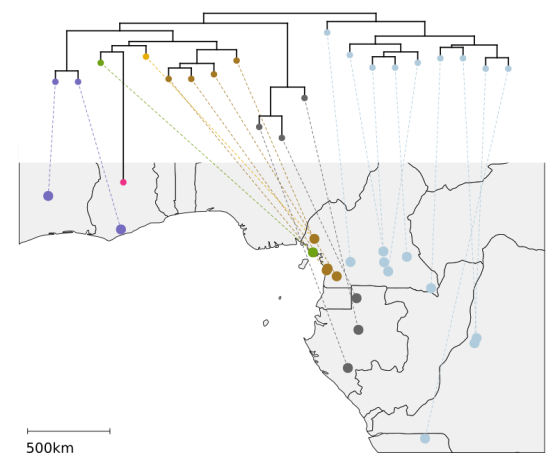

Figure 3. (a) scatterplot of $R$. hookeri complex based on 915 SNPs; (b) scatterplot of $R$. zamiana complex based on 1627 SNPs. Clades representing the (c) R. hookeri and (d) R. zamiana complexes were extracted from the ASTRAL (Figure 1) tree and linked to their locations on a map of central Africa (area in context on inset map). Individuals are colored by the colors corresponding to SODA species delimitation, an approach that uses gene tree topologies to determine whether coalescence is random or non-random and delimit species based on this. We depict SODA results for two different values of $\alpha$ (confidence): 0.01 in $(\mathbf{a}, \mathbf{c})$ and 0.005 in $(\mathbf{b}, \mathbf{d})$. An individual belonging to $R$. taedigera (RA_TA) is not shown in panels (a) and (c) due to missing data.

\section{Discussion}

\subsection{Synthesizing Morphology and Molecules: The Sections of Otedoh Reevaluated}

Our phylogenomic analyses of Raphia provide a novel and overall well supported phylogenetic framework for this important African genus (Figure 1A). Although some of the morphology-based sections of Otedoh [21] were recovered, we also recovered some topological differences (Figure 1A).

The Moniliformes and Flabellatae are not recovered as monophyletic. The Moniliformes are split into two clades, while the two Flabellatae species (Raphia farinifera, R. vinifera) are not recovered as sister and are nested within the Moniliformes section (Figure 1). In addition, the phylogenetic placement of the Moniliformes species R. matombe from the Democratic Republic of the Congo and Angola (including Cabinda) was different between the two types of analyses (Figure 2).

In all analyses, the acaulescent central African species Raphia regalis is recovered with strong support as sister to the rest of the genus (Figures 1A and A1). This species, together with $R$. australis, were placed within the subsection "erectae" within the Moniliformes section [20,21] because the inflorescences were suggested to be "erect", in contrast to the rest of the Raphia species whose inflorescences are hanging or semi-erect (except for $R$. palma-pinus which also has an erect inflorescence). Our results do not support this classification, as R. australis is recovered as sister to $R$. farinifera (of the Flabelattae section, Figure 1) and phylogenetically divergent from $R$. regalis. A closer observation in the field showed that only the inflorescences of $R$. australis are truly erect (Figure $1 \mathrm{~N}$ ). In 
contrast, the inflorescences of $R$. regalis appear erect but are in fact "supported" by the large leaves and not truly erect (Figure 1G).

The close relationships between the Moniliformes and Flabellatae section are not surprising. The inflorescences, although different in some aspects such as the clearly racket-shaped partial inflorescences of the Flabellatae section, show certain similarities not encountered in other Raphia species. Both have thin rachillae and the partial inflorescences are subtended by large showy bracts at least in the younger stages of development. These morphological similarities thus support the close phylogenetic relationships recovered here between these two sections.

The Obclavate section, composed of the sole species $R$. sudanica, is recovered with strong or moderate support as sister to the Raphiate section. This species presents a unique inflorescence structure within the genus that is reduced and compressed into a cylindrical shape (Figure 1C), with large bracts covering the partial inflorescences almost completely [20,21,27]. In addition, and in contrast to most species, $R$. sudanica thrives within the drier regions of the Sahel along small stream courses. These distinctive characters and its phylogenetic position support it being placed in a section of its own, confirming the classification of Otedoh [21].

Finally, the two remaining sections, Raphiate and Temulentae, are recovered as monophyletic, although with varying levels of support from strong to moderate (Figures $1 \mathrm{~A}$ and A1). This also confirms the classification of Otedoh [21] and the usefulness of partial inflorescence shapes in the classification of Raphia species.

Our results, however, suggest that certain sections erected by Otedoh [21] are not monophyletic and need to be re-evaluated. Differences in phylogenetic relationships between the concatenated and coalescent approaches have been increasingly reported in this genomic era [28-30]. Our results were similar to those in Couvreur et al. [19] where higher bootstrap support was obtained when using the concatenation approach, despite the coalescent approach highlighting considerable gene tree conflict. Here, we favor the phylogenetic hypothesis recovered when using the coalescent approach (Figure 1) because these methods allow gene history to be taken into account [31] and provide an arguably more realistic reconstruction of phylogenetic relationships when using a large number of independently evolving nuclear markers as used here. Our analyses suggest that we can retain five sections, only slightly different than those initially defined by Otedoh [21]. Three sections have been reconstructed in the phylogeny: Obclavatae (with its only species R. sudanica), Raphiate, and Temulentae. The latter two sections are internally complicated, and more discussion about the phylogenetic relationship within sections is provided below. The main problem thus comes from the Moniliformes and Flabellatae sections, which are not monophyletic. Raphia regalis should be placed in a section of its own, linked to its unique morphology being an acaulescent species with large inflorescences subtended by large leaves (Figure 1G). Finally, the last section should regroup all the other species from both the Moniliformes and Flabellatae.

We thus recognize five main sections within Raphia based on the phylogenetic results presented here. We then discuss these results in more detail below.

1. Section Erectae (Otedoh) Couvreur, Mogue, and Sonké, sect. nov.. Type species: R. regalis Becc.

Diagnose: Acaulescent palms with less than ten leaves. Inflorescences erect amongst leaves, rachillae thin, and brittle. Although the inflorescences are not truly erect (see above), we prefer to conserve the name "Erectae" for this new section. Contains to date one species: R. regalis.

2. Section Moniliformes Otedoh. Type species: R. textilis Welw. This section also includes the species formally placed in section Flabellatae by Otedoh [21]. Because the name Moniliformes was published before Flabellatae (page 148 versus 163), we retained the former name here. A section with seven recognized species: $R$. australis, $R$. farinifera, $R$. gentiliana De Wild., R. matombe De Wild., $R$. ruwenzorica Otedoh, $R$. textilis Welw. and R. vinifera P.Beauv. (sensus Kamga Mogue et al. [32]).

3. Section Temulentae Otedoh. Type species: R. hookeri Mann and Wendl. This section remains the same as defined by Otedoh [21]. We also include the newly described species $R$. gabonica [7] in this section. 
A section with four recognized species: R. gabonica Mogue, Sonké, Couvreur, R. hookeri Mann and Wendl., R. sese De Wild. and R. rostrata Burret.

4. Section Raphiate Otedoh. Type species: R. palma-pinus (Gaertn.) Hutch.. Otedoh [21] had an erroneous vision of $R$. vinifera (the type of this section) which does not belong to the Raphiate section (see [32] for details). We thus choose a new type species being the second oldest name within this section.

A section with eight recognized species: $R$. africana Otedoh, $R$. laurentii De Wild., $R$. longiflora Mann and Wendl., R. mannii Becc., R. monbuttorum Drude, R. palma-pinus (Gaertn.) Hutch., R. taedigera Mart. and R. zamiana Mogue, Sonké, Couvreur.

5. Section Obclavatae Otedoh. Type species: $R$. sudanica Chev.. One single species is recognized in this section: R. sudanica

\subsection{Species Delimitation and Species Complexes}

Phylogenetic relationships between species are well to weakly resolved depending on the section, as discussed below.

\subsubsection{The Moniliformes (Including Flabellatae) Section}

Within the Moniliformes section, species relationships are generally strongly supported (Figures 1 and A1) and several species are recovered as monophyletic (R. australis, R. farinifera, R. matombe) while species limits in others are less clear ( $R$. textilis, $R$. vinifera).

Once again, there is a conflict between the concatenated and coalescent analyses. Raphia textilis is split into two well-supported clades in the former analysis (Figure A1), while it is recovered as monophyletic with strong support in the latter (Figure 1). Nevertheless, there is little doubt that these samples represent the same species as they are morphologically similar. This is also confirmed by the species delimitation analysis at both levels of $\alpha$ (Figures 1 and A2).

Another result recovered is the close relationship of the two montane species of Raphia: $R$. ruwenzorica been included within $R$. vinifera. Both species occupy a similar ecological and altitudinal ranges, despite being geographically separated by ca. $2500 \mathrm{~km}$. Raphia vinifera, of which most samples were in the past identified as $R$. mambillensis and now a synonym of $R$. vinifera, occurs mainly in Cameroon and Nigeria, where it grows between 1200 and $2000 \mathrm{~m}$ in grassland or open vegetation and is very abundant along streams and rivers [10,32]. Raphia ruwenzorica occurs between 800 and $1500 \mathrm{~m}$ in the Albertine rift region in eastern Democratic Republic of the Congo and Burundi and has been suggested to grow in "savanna country" along valleys [20,21,33,34]. In addition, both species present similar partial inflorescences that are flat and racket shaped. However, both species differ markedly in their port with $R$. ruwenzorica reported to have a distinct tall stipe reaching up to $15 \mathrm{~m}[10,21,33]$, whereas as $R$. vinifera is acaulescent or with a short stipe (less than $1 \mathrm{~m}$; [32]). This, in addition to the 2500+ km separating these species, suggests that they could be recognized as distinct, despite our results. Interestingly, a within species CVL/Albertine rift disjunction has been documented in different taxa such as Isolona congolana (Annonaceae [35]) and Prunus africana [36].

Raphia farinifera is the most widespread species of Raphia, occurring from West to East Africa and Madagascar, and has also been reported from the Republic of Congo and Angola [23,34,37-42]. Our limited (3) but widespread sampling (West, Central Africa, and Madagascar) of individuals clustered together with maximum support (Figures 1 and A1). However, our species delimitation analysis suggests that the Malagasy individual (R41_T15) is a different species (Figure 1). Interestingly, Raphia individuals from Madagascar were initially described as a different species ( $R$. ruffia and also once described as $R$. tamatavensis Sadeb.) [22,34] and the name subsequently synonymized with R. farinifera [34,40]. In Madagascar, Raphia is widely used (one of the most useful palms) and, today at least, not found in natural forests across the island [43]. This has led to the hypothesis that Raphia was introduced 1500 years ago during the first wave of human colonization of the island [43]. However, several authors suggested that this species used to occur naturally and abundantly 
in some places of the Island [22,44]. Our sampling is not extensive enough to answer this question conclusively, but our results suggest that Malagasy individuals might indeed belong to a different species (R. ruffia) as concluded by Beccari [22] (p. 53) thus not supporting the recent introduction hypothesis. Finally, $R$. farinifera is recovered as sister to $R$. australis, a relationship already suggested based on morphology [34].

\subsubsection{The Raphiate Section}

This is one of the most complex and least understood sections. Some of these species are poorly known and rarely collected, sometimes only known from a single poor quality specimen (R. africana; R. longiflora; R. mannii). In our study, we were not able to sample R. mannii and R. longiflora, thus our results for this section are still incomplete. Overall, the relationships between species in the Raphiate section are weakly to moderately supported in both analyses (Figures 1 and A1). Nevertheless, we do recover monophyletic groups in some species consistent with prior morphological identifications. This is the case for individuals of R. laurentii and R. monbuttorum, which despite low support are monophyletic. Furthermore, both these species are recovered as sister, with moderate to high support. However, our species delimitation analysis suggests that individuals identified under both species are conspecific (Figure 1A). Indeed, these two species are morphologically similar [19], having clustering stipes covered with straight fibers in addition to having semi-erect inflorescences when young (Figure 1 I), an unusual character within the genus. Nevertheless, it is hard morphologically to consider these two species as conspecific. Indeed, the shape of the rachillae is quite different between these species (Figure 1J,K). Raphia laurentii is characterized by rather thick rachillae covered by numerous tightly packed rachis bracts leading to an overall digitate aspect of the rachillae (Figure 1J). In R. monbuttorum, the rachillae are thinner and the rachis' bracts are less tightly packed around the rachillae (Figure $1 \mathrm{~K}$ ). These differences appear to be consistent and provide useful identification characters [19].

Raphia zamiana was recently described [7]. Our broad sampling of this species, however, recovers R. zamiana as polyphyletic, with individuals grouping into two main clades, flagged as two different species by our species delimitation analysis (Figures 1 and A2). Interestingly, these two species are geographically distinct, with one clade sampled across Gabon and one across Cameroon (Figure 3b,d), the latter containing the type of R. zamiana. The Gabon cluster is particularly well supported in both analyses. At this point, however, it is hard to pin point clear morphological characters differentiating these two clusters, as extensive field observations have yet to distinguish them properly.

We sampled two individuals of the Neotropical species R. taedigera, both from Brazil. As expected from the morphology of the partial inflorescence [21], this species grouped within the Raphiate section (Figure 1). Both individuals clustered together with strong support, and, in turn, were recovered as sister to either R. africana (Figure 1) or R. palma-pinus (Figure A1, in both cases with weak support values). Otedoh [21], following certain authors [23,45], suggested that $R$. taedigera was very close morphologically to a species he called $R$. vinifera. However, early on, the taxonomic concept of $R$. vinifera has been confusing, erroneously mistaking this species for a Raphiate type species [23,45]. Mogue Kamga et al. [32] clarified the situation showing that the name $R$. vinifera refers to a Flabelattae species mainly occurring in the CVL. To date, it remains unclear to what species Otedoh and others $[21,23,45]$ were referring to when invoking $R$. vinifera.

Despite these taxonomic confusions, our results provide some indication as to the origin of $R$. taedigera in the Neotropcis. It has been hypothesized that this species originated as a result of vicariance during the breakup of Gondwana [4]. The deeply nested position of $R$. taedigera within the genus does not support this hypothesis. Instead, our results lend some support to the conclusion of Otedoh [10] who suggested that $R$. taedigera did not show any "primitive" characters within the genus. Otedoh went further to suggest that $R$. taedigera was the result of a recent introduction in South and Central America during the slave trade some 400 years ago $[10,11]$. Our species delimitation results suggest, however, that $R$. taedigera is a valid species (Figure 1), at least based on the individuals 
sampled from Brazil. Finally, Otedoh also suggested the presence of $R$. taedigera in coastal west-central Africa $[10,11]$. However, to date, we have not been able to locate this species in African collections and this hypothesis remains doubtful [1]. Our phylogenetic analyses suggest that $R$. taedigera is genetically quite different from other Raphia species (Figure A2) supporting the hypothesis that it must have dispersed to the Neotropics more than 400 years ago. This would fit with paleoecological data from Nicaragua documenting $R$. taedigera pollen over the last 2500 years [9]. A more detailed sampling of $R$. taedigera from the Neotropics together with a dated molecular phylogeny approach will provide a better understanding of the biogeographic history of this interesting trans-Atlantic disjunction.

\subsubsection{The Temulentae Section}

This section contains the species referred to as the "wine" palms $[20,21]$ with three species previously included in this section ( $R$. hookeri, R. rostrata, R. sese), all of which are sampled here. In addition, our results show that the newly described species, $R$. gabonica [7], is also part of the Temulentae section. This was not clear at the time of the publication as the partial inflorescence suggested a possible relationship with the Moniliformes section [7]. Overall, species identified based on morphology clustered together (e.g., R. gabonica, R. sese) with strong or low support (Figure 1 and Figure A2). Nevertheless, all four species show a very close phylogenetic proximity, suggesting that this section could be regarded as a species complex. Indeed, depending on the level of stringency used for the SODA analysis, our species delimitation analysis recovered either seven distinct species or one single species (Figure 1 and Figure A2). It is important to note that changing levels of $\alpha$ did not impact species delimitation in the other sections. Morphologically, however, these species are different and can easily be identified in the field, which is partly supported by our phylogenetic analysis. For example, $R$. gabonica resembles $R$. hookeri in the clearly visible single stipe covered with characteristic curly fibers, but differs markedly by being a terra firme low-density species with thin (Moniliformes-like) and densely packed rachillae. In contrast, $R$. hookeri is a swampy species, growing in large, monodominant stands with robust and more evenly-spaced rachillae $[7,19]$. In the same way, $R$. rostrata is characterized by a small but clustering stipe with mixed curly and straight hanging fibers and occurs along rivers with strong currents [19].

Raphia hookeri is recovered here as polyphyletic, possibly including four different cryptic species. This is one of the most important, abundant, and widespread Raphia species and its overall morphology is rather constant across its range. However, individuals appear to be geographically structured like in R. zamiana (see above). Interestingly, this mirrors patterns of genetic structure recovered across a wide range of central African plant species [46,47], including R. zamiana.

\section{Materials and Methods}

\subsection{Species Sampling, Library Preparation, and DNA Sequencing}

We sampled a total of 56 individuals (see Table A1 in Appendix A for details) representing 18 out of the 21 species accepted to date [7,19] and representing all sections described by Otedoh [21]. In order to collect proper material for sequencing, several field trips were undertaken across several African countries including Ivory Coast, Ghana, Gabon, Cameroon, Angola, and the Demographic Republic of the Congo between 2012 and 2017. We were not able to access material from three accepted species: R. gentiliana, R. mannii, and R. longiflora. We sampled two to seven individuals per species in order to test for monophyly. However, only a single specimen was available for $R$. ruwenzorica. Finally, we sampled four species within Calamoideae as outgroups: Eremospatha cabrae, Eremospatha quinquecostulata, Laccosperma cristalensis, and Mauritiella armata following [25,48]. We extracted DNA from leaves dried in silicagel, except for one individual of $R$. taedigera and the only individual of $R$. ruwenzorica for which DNA was extracted from herbarium material.

Methods for DNA extraction, preparation of sequencing libraries, hybridization, Illumina MiSeq DNA sequencing, and read cleaning followed [19]. In brief, barcoded Illumina libraries were 
constructed based on a modified protocol of Rohland and Reich [49]. We hybridized DNA to defined exons using the palm-specific nuclear baiting kit of Heyduk et al. [26]. This kit allows for sequencing exons from 176 nuclear genes across the palm family.

\subsection{Contig Assembly and Multi-Sequence Alignment}

We used HybPiper (v1.2) [50] to process our cleaned reads (following [19]) to obtain sequences corresponding to the target exons plus associated intronic sequence data (referred to as supercontigs).

Briefly, we demultiplexed the data and removed adapters. Reads were filtered according to their length $(>35 \mathrm{bp})$ and quality mean values $(\mathrm{Q}>30)$. We trimmed $6 \mathrm{bp}$ of sequences to ensure removal of barcodes when sequences were shorter than $150 \mathrm{bp}$. Reads were then mapped to target exons and successfully mapped reads were assembled into contigs. These contigs were then aligned to their associated target exon sequence. If contigs were slightly overlapping [50], they were combined into "supercontigs" which contain both target and off-target sequence data. We aligned each set of supercontigs using MAFFT (v7.305) [51] with the -auto option and cleaned these alignments with GBLOCKS (v0.91b) [52] using the default parameters and all allowed gap positions.

To identify a suitable set of loci for phylogenetic inference, we selected only those supercontigs that had $75 \%$ of their exon length reconstructed in at least $25 \%$ of individuals (referred to as $75 / 25$ ). We used only those loci in which at least $75 \%$ of the exon length was recovered because the use of fragmented sequences is known to increase gene tree error, whereas the number of individuals has little effect as long as the gene tree is accurate [53].

Paralog Identification

HybPiper flags potential paralogs when multiple contigs are discovered mapping well to a single reference sequence. We ran hybpiper on the 837 exons that made up the baiting kit [26], identified flagged loci, and constructed exon trees using RAxML (v8.2.9) [54]. We examined each tree to determine whether putative paralogs formed a species clade. When sequences concerning more than three individuals were flagged for a locus, we examined whether the 'main' and alternative sequences formed separate clades. If so, this locus was classified as a paralog and discarded from the dataset. For each gene, we then calculated at the proportion of exons that we confirmed as paralogs after inspection. If this proportion was $<50 \%$, we removed the entire gene from our analyses.

\subsection{Coalescent Phylogenetic Inference}

Individual gene trees were constructed with 100 bootstraps and the GTRGAMMA model using RAxML (v8.2.9) [54] (option "-f a"). If, after inference, branches had bootsrap support values $>10$, they were collapsed using the program nw_ed [55] because this approach has been shown to improve the accuracy of ASTRAL [31]. We used the selected 75/25 gene trees as our input to run ASTRAL-III (v5.5.11) [31] using the default options.

\subsection{Species Delimitation}

After constructing our ASTRAL tree, we used the associated approach SODA [56]. Simulations using this approach have shown it to be of similar accuracy or more accurate [56] than other popular species delimitation methods such as BPP [57] at a fraction of the computational cost. SODA uses frequencies of quartet topologies to determine if each branch in a guide tree inferred from gene trees (i.e., the ASTRAL tree from above) is likely to have a positive length. This identifies where in the tree coalescence is random, and where it is non-random. It then uses the results to infer a new, extended species tree that defines boundaries among species. We used two cut-off values of $\alpha$ (confidence level): 0.01 and 0.005 . 


\subsection{Maximum-Likelihood Phylogenetic Inference}

After suitable loci were identified, we filled any missing individuals in each alignment with an empty sequence. We then concatenated all aligned loci using the pxcat function in the program phyx [58]. We used IQ-TREE (v1.6.8; [59]) to infer a maximum likelihood tree of all individuals. We partitioned our dataset so that each supercontig had a separate substitution model and used the following options when running the program: “-m MFP + MERGE -rcluster 10 -bb 1000 -alrt 1000". We selected the optimal partitioning scheme using ModelFinder [60], choosing the best model based on Bayesian Information Criterion (BIC) score and merging genes until model fit stopped increasing. We also used rcluster [61] to decrease computational load. We made use of the ultrafast bootstrapping ([62]; 1000 replicates) and the SH-like approximate likelihood ratio test ([63]; 1000 replicates) to assess branch support in the tree.

\subsection{SNP Calling}

To call SNPs, we first used SeCaPr (v1.1.4; [64]) to build a psuedoreference. After filtering out low coverage and paralogous loci, consensus sequences are built and combined to form a reference file that is closer to the study group than the original, and will recover more data. We mapped our cleaned, paired reads to this new, dataset-specific reference using BWA (v0.7.12; [65]). Duplicates were removed and we called SNPs using the program HaplotypeCaller in GATK (v4.0; [66]). We applied thresholds to mapping quality $(>40 \%)$ depth $(>25)$, quality by depth $(>2)$, minimum quality across all individuals $(>10)$ and minor allele frequency $(>0.01)$ to filter SNPs using bcftools (v1.8; [67]). We kept only biallelic SNPs and excluded monomorphic sites.

\subsection{Genetic Clustering}

We performed Discriminant Analysis of Principal Components (DAPC) [68] to identify genetic clusters in two species complexes of Raphia. We used the function find.clusters in the R package 'adegenet' [69] to infer the number of clusters using successive K-means with 100,000 iterations per value of $k$ up to $k=20$. We used BIC to identify the best-fitting number of clusters. We then used the function dapc [68] to define the diversity among the clusters identified. We chose the optimum number of axes to use with the function optim.a.score.

\section{Conclusions}

Our results provide a new step forward in understanding the phylogenetic relationships and taxonomy within this major African palm genus. We show that the morphological sections based on partial inflorescence shape defined by Otedoh [21] are relatively robust overall. Sections Obclavatae, Temulentae, and Raphiate are recovered as monophyletic with good support, while sections Moniliformes and Flabellatae are not. We thus redefined these later two sections into sections Erectae, composed of $R$. regalis, and Moniliformes, including all species previously included in Flabellatae. Our results also uncover important species delimitation problems defined here as species complexes ( $R$. hookeri, R. zamiana) that must be solved if we are to have a thorough understanding of Raphia systematics. Given the economic and ecological importance of $R$. hookeri, clarifying its species delimitation will be important in the future. Different approaches could rely on more in-depth population level studies using more variable markers (e.g., microsatellites) combined with detailed morphometric measurements as has been done in other African tree species, e.g., [70-72]. A better comprehension of the taxonomy and the phylogenetic relationships in Raphia represents a fundamental tool towards the proposal of conservation strategies aiming to characterize genetic and morphologic diversity in this ecological and economically important genus. Finally, we show here that the Heyduk et al. baiting kit [26] is useful for understanding relationships within the Raphia genus and between species as was shown in other groups e.g., [73], although it appears to be limited for untangling species complexes. Resolving relationships within Raphia will thus rely on more data, including 
increased infra-species sampling, detailed morphological studies in certain species, and larger baiting kits, e.g., [74].

Author Contributions: Conceptualization, T.L.P.C. and B.S.; methodology K.B. and A.J.H.; validation A.J.H., F.S.B., and S.M.K.; formal analysis A.J.H.; resources T.L., F.S., C.D.B., J.J.W., A.Z., A.A., S.M.K., and T.L.P.C.; data curation K.B., A.J.H., and S.M.K.; writing-original draft preparation A.J.H. and T.L.P.C.; writing-review and editing, all authors; supervision, T.L.P.C. and B.S.; project administration, T.L.P.C.; funding acquisition, T.L.P.C. All authors have read and agreed to the published version of the manuscript.

Funding: This study was supported by Agropolis Fondation (RAPHIA project) under the reference ID 1403-026 through the «Investissements d'avenir» program (ANR-10-LABX-0001-01; ISITE MUSE: ANR-16-IDEX-0006) and Agence Nationale de la Recherche (ANR-15- CE02-0002-01, AFRODYN project), both to T.L.P.C.. This work was also part of the PALM-A-GOV (project number: 1702-007) project to T.L.P.C., publicly funded through the ANR (the French National Research Agency) under the "Investissements d'avenir" program with the reference ANR-10-LABX001-01 Labex Agro and coordinated by Agropolis Fondation within the I-SITE MUSE (ANR-16-IDEX-0006). The International Palm Society (IPS) provided important and crucial financial support for field trips to The Democratic Republic of the Congo (to S.M.K.), Republic of the Congo and Cameroon (to T.L.P.C.). A.Z. is funded by iDiv via the German Research Foundation (DFG FZT 118), specifically through sDiv, the Synthesis Centre of iDiv. C.D.B. is funded by the Swedish Research Council (2017-04980). A.A. is funded by the Swedish Research Council, the Swedish Foundation for Strategic Research, the Knut and Alice Wallenberg Foundation and the Royal Botanic Gardens, Kew. J.J.W. received funding for travel from the Alberta Mennega foundation.

Acknowledgments: The authors acknowledge the IRD itrop HPC (South Green Platform) at IRD Montpellier for providing HPC resources that have contributed to the research results reported within this paper. We are grateful to the Centre National de la Recherche Scientifique et Technique (CENAREST) in Gabon and the Agence National des Parques Nationaux (ANPN) for delivering the necessary research permits for our field work in Gabon in 2015 and 2016 (permits AR0020/16; AR0036/15, AR0035/15 (CENAREST) and AE16014; AE15027 (ANPN)). Paul Henri Bourobou Bourobou is thanked for his assistance in obtaining these research permits, while Raoul Niangadouma and Narcisse Kamdem are thanked for their help in the field. Fieldwork in Cameroon was undertaken under the "accord cadre de cooperation" between the IRD and Ministère de la Recherche Scientifique et Technique (MINRESI). Field work in the Republic of Congo was undertaken under the research permit \#003 in 2014 delivered to Adama Faye (IRD). We thank Moutsambote for assistance and help with this permit. TU Dresden maintains a Memorandum of Understanding with the Instituto Nacional da Biodiversidade e Áreas de Conservação (INBAC) of the Ministério do Ambiente da República de Angola that includes collection and export permits.

Conflicts of Interest: The authors declare no conflict of interest.

\section{Abbreviations}

The following abbreviations are used in this manuscript:

CVL Cameroon Volcanic Line

SNP Single Nucleotide Polymorphism

PCA Principal Components Analysis 


\section{Appendix A}

Table A1. Herbarium specimen collector and number and herbarium origin, coordinates (in decimal degrees) and country of collection for all samples included in our study. All samples were extracted from silicagel dried leaves, expect when stated otherwise. The last five columns refer to the sequencing identification (TAG and INDEX used) and different sequencing statistics (number of reads mapped to the reference; mean and standard depth, respectively).

\begin{tabular}{|c|c|c|c|c|c|c|c|c|c|c|c|}
\hline Genus & Species Epithet & ID & Collector (Herbarium) & Country & Latitude & Longitude & Run & Tag & No. Mapped & Mean Depth & Stdev Depth \\
\hline Eremospatha & cabrae & R227 & $\begin{array}{ll}\text { Couvreur } 1165(\text { WAG) } \\
\end{array}$ & Cameroon & 3.128984 & 9.973292 & 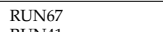 & TAG-28 & 441,790 & 315.48 & 469.205 \\
\hline Eremospatha & $\begin{array}{l}\text { quinquecostulata } \\
\text { cristolensis }\end{array}$ & B164 & $\begin{array}{ll}\text { Couvreur } 1079(\mathrm{WAG}) \\
\end{array}$ & & & & & TTG39 & & & 68.317 \\
\hline $\begin{array}{l}\text { Laccosperman } \\
\text { Maurititlla }\end{array}$ & $\begin{array}{l}\text { cristalensis } \\
\text { armata }\end{array}$ & $\begin{array}{l}\text { R1646 } \\
\text { R135 }\end{array}$ & $\begin{array}{l}\text { Couvreur 1142 (NAG) } \\
\text { Couvreur } 257 \text { (NY) }\end{array}$ & $\begin{array}{l}\text { Gabon } \\
\text { Bolivia }\end{array}$ & 013496289 0.0059 & $\begin{array}{l}10.4118 \\
-68019923\end{array}$ & $\begin{array}{l}\text { RUN411 } \\
\text { RUN37 }\end{array}$ & $\begin{array}{l}\text { TAG41 } \\
\text { TAG6 }\end{array}$ & $\begin{array}{l}10,03200 \\
406,12\end{array}$ & 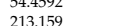 & $\begin{array}{l}86.7457 \\
12446\end{array}$ \\
\hline Raphia & africana (cf) & R072 & Couvreur 971 (WAG) & Cameroon & 4.87036 & 9.26579 & RUN41 & TAG10 & 121,972 & 63.533 & 69.0331 \\
\hline Raphia & africana (cf) & R077 & No voucher, close to Couvreur 971 (WAG) & Cameroon & 4.87064 & 9.26582 & RUN33 & TAG43 & 315,915 & 159.931 & 188.084 \\
\hline Raphia & africana (cf) & R174 & No voucher, close to Couvreur 971 (WAG) & 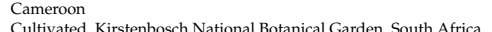 & 4.12977 & 9.21399 & RUN41 & TAG47 & 50,272 & 26.0156 & 28.656 \\
\hline $\begin{array}{l}\text { Raphpia } \\
\text { Raphia }\end{array}$ & $\begin{array}{l}\text { austrfatis } \\
\text { australis }\end{array}$ & $\begin{array}{l}\text { R092 } \\
\text { R130 }\end{array}$ & $\begin{array}{l}\text { MBC } 98 \text { 87DD (SABND) } \\
\text { MBC } 998 \text { 874D (SANBI) }\end{array}$ & 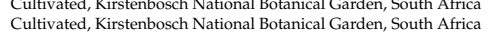 & $\begin{array}{l}\text { NAA } \\
\text { N/A }\end{array}$ & $\begin{array}{l}\text { NAA } \\
N / A\end{array}$ & 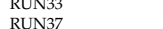 & 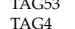 & $\begin{array}{l}25,5329 \\
913,67\end{array}$ & $\begin{array}{l}129.65 \\
473.13\end{array}$ & $\begin{array}{l}156.525 \\
627.945 \\
6\end{array}$ \\
\hline Raphia & $\begin{array}{l}\text { farinifisera } \\
\text { fall }\end{array}$ & R128 & Faye 36 (WAG) & Republic of Congo & -3.99056 & 11.30600 & RUN37 & TAG1 & 476,130 & 245.7 & 292.787 \\
\hline $\begin{array}{l}\text { Raphia } \\
\text { Raphia }\end{array}$ & $\begin{array}{l}\text { farinififera } \\
\text { farififra }\end{array}$ & $\begin{array}{l}\mathrm{R} 127 \\
\mathrm{R} 122\end{array}$ & $\begin{array}{l}\text { Baker s.n. (K, DNA bank id: } 14927) \\
\text { Dransfiel } 75616(\mathrm{~K})\end{array}$ & Cultivated, Royal Botanic Gardens, Kew, U.K. & & $\mathrm{NA}$ & $\begin{array}{l}\text { RUN37 } \\
\text { RUN41 }\end{array}$ & TAG105 & 486,723 & 250.42 & 309.47 \\
\hline 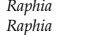 & $\begin{array}{l}\text { fariniferca } \\
\text { gabonica }\end{array}$ & $\begin{array}{l}\text { R132 } \\
\text { R034 }\end{array}$ & $\begin{array}{l}\text { Dransfield 7516 (K) } \\
\text { Kamga Mogue 22 (WAG) }\end{array}$ & Madagascar & $\begin{array}{l}-1.84988 \\
-0.0976\end{array}$ & 13.85903 & RUN41 & $\begin{array}{l}\text { TAG15 } \\
\text { TAC23 }\end{array}$ & $\begin{array}{l}133,441 \\
28443\end{array}$ & 68.7643 & 85.4757 \\
\hline $\begin{array}{l}\text { Raphphia } \\
\text { Raphia }\end{array}$ & $\begin{array}{l}\text { gabohina } \\
\text { gabonica }\end{array}$ & $\begin{array}{l}\text { R034 } \\
\text { R036 }\end{array}$ & $\begin{array}{l}\text { Kamga Mogue } 22 \text { (WAG) } \\
\text { Kamga Mogue } 23 \text { (WAG) }\end{array}$ & $\begin{array}{l}\text { Gabon } \\
\text { Gabon }\end{array}$ & $\begin{array}{l}-0.09716 \\
-1.03044\end{array}$ & $\begin{array}{l}11.00836 \\
10.5881\end{array}$ & $\begin{array}{l}\text { RUN33 } \\
\text { RUN33 }\end{array}$ & $\begin{array}{l}\text { TAG23 } \\
\text { TAG24 }\end{array}$ & $\begin{array}{l}2842,433 \\
212,252\end{array}$ & $\begin{array}{l}143.822 \\
108.979\end{array}$ & $\begin{array}{l}174.031 \\
13.141\end{array}$ \\
\hline Raphia & $\begin{array}{l}\text { hookeri } \\
\text { hoon }\end{array}$ & $\mathrm{R} 063$ & Kamga Mogue 1 (WAG) & Cameroon & 3.07485 & 13.3663 & RUN33 & TAG35 & 319,096 & 162.68 & 210.004 \\
\hline Raphia & $\begin{array}{l}\text { hookeri } \\
\text { bohere }\end{array}$ & R069 & Kamga Mogue 12 (WAG) & Cameroon & 3.97037 & 13.2367 & RUN33 & TAG39 & 197,508 & 100.49 & 122.815 \\
\hline $\begin{array}{l}\text { Raphia } \\
\text { Raphia }\end{array}$ & $\begin{array}{l}\text { hookeri } \\
\text { hookeri }\end{array}$ & $\begin{array}{l}\text { R071 } \\
\text { R124 }\end{array}$ & $\begin{array}{l}\text { Kamga Mogue } 26 \text { (WAG) } \\
\text { Courreur 984 (WAG) }\end{array}$ & $\begin{array}{l}\text { Cameroon } \\
\text { Cameroon }\end{array}$ & $\begin{array}{l}4.11224 \\
3.52108\end{array}$ & $\begin{array}{l}9.56915 \\
1174376\end{array}$ & $\begin{array}{l}\text { RUN33 } \\
\text { RUN41 }\end{array}$ & $\begin{array}{l}\text { TAG41 } \\
\text { TAG14 }\end{array}$ & ${ }_{78,554}^{292,01}$ & $\begin{array}{l}149.509 \\
40.846\end{array}$ & $\begin{array}{l}181.385 \\
44,4911\end{array}$ \\
\hline $\begin{array}{l}\text { Rapplaa } \\
\text { Raphia }\end{array}$ & $\begin{array}{l}\text { hookert } \\
\text { hookeri }\end{array}$ & 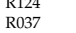 & $\begin{array}{l}\text { Oouvreur } 984 \text { (WAG) } \\
\text { Kamga Mogue } 25 \text { (WAG) }\end{array}$ & $\begin{array}{l}\text { Cameroon } \\
\text { Gabon }\end{array}$ & $\begin{array}{l}3.52108 \\
-0.82955\end{array}$ & $\begin{array}{l}11.74376 \\
10.52294\end{array}$ & $\begin{array}{l}\text { RUN41 } \\
\text { RUN33 }\end{array}$ & $\begin{array}{l}\text { AAG14 } \\
\text { TAG25 }\end{array}$ & $\begin{array}{l}78,54 \\
278.678\end{array}$ & $\begin{array}{l}40.8646 \\
142.219\end{array}$ & $\begin{array}{l}44.4991 \\
175.028\end{array}$ \\
\hline Raphia & hookeri & R089 & $\begin{array}{l}\text { Michon } 01 \text { (G) } \\
\text { late) }\end{array}$ & Togo & 6.39183 & 2.67703 & RUN33 & TAG51 & 201,880 & 103.103 & 124.193 \\
\hline Raphia & $\begin{array}{l}\text { laurentiii } \\
\text { laturutit }\end{array}$ & R208 & Lautenschlagger 806 (JACQ) & Angola & -6.14997 & 15.40333 & RUN46 & TAG18 & $\begin{array}{l}64,379 \\
772500\end{array}$ & 34.3542 & 37.7478 \\
\hline Raphia & 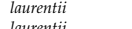 & R040 & Ayole 01 (YA) & Cameroon & $\begin{array}{l}2.15329 \\
-0.8592\end{array}$ & 15.7367 & $\begin{array}{l}\text { RUN33 } \\
\text { RUN46 }\end{array}$ & TAG26 & $\begin{array}{l}272,509 \\
{ }_{27}=509\end{array}$ & 138.397 & 168.066 1066 \\
\hline $\begin{array}{l}\text { Kapphia } \\
\text { Raphia }\end{array}$ & $\begin{array}{l}\text { laburenthl } \\
\text { laurentii }\end{array}$ & 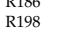 & $\begin{array}{l}\text { Kamga Mogue } 39 \text { (WAG) } \\
\text { Kamga Mogue } 42 \text { (WAG) }\end{array}$ & 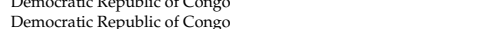 & $\begin{array}{l}-0.8882 \\
-0.60673\end{array}$ & $\begin{array}{l}18.1337 \\
18.2468\end{array}$ & $\begin{array}{l}\text { RUN46 } \\
\text { RUN46 }\end{array}$ & $\begin{array}{l}\text { IAGIO } \\
\text { TAG14 }\end{array}$ & $\begin{array}{l}878388 \\
86786\end{array}$ & $\begin{array}{l}4.14035 \\
465246\end{array}$ & $\begin{array}{l}51.2042 \\
51853\end{array}$ \\
\hline Raphia & matombe & & 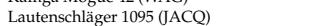 & & -7.94817 & 15.83894 & & & & & $\begin{array}{l}51.1833 \\
347279\end{array}$ \\
\hline Raphia & matombe & R134 & 19392103 (BR) & Cultivated, Meise Botanical Garden, Belgium & $\mathrm{NA}$ & 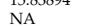 & RUN41 & TAG16 & $\begin{array}{l}77,250 \\
76,250\end{array}$ & 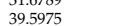 & 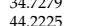 \\
\hline Raphia & matombe & R181 & Kamga Mogue 37 (WAG) & Democratic Republic of & -5.73485 & 14.2162 & RUN46 & TAGS & $\begin{array}{l}55,883 \\
\end{array}$ & 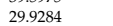 & 31.68 \\
\hline $\begin{array}{l}\text { Raphia } \\
\text { Rahpia }\end{array}$ & matombe & R183 & Kamga Mogue 38 (WAG) & Democratic Republic of Congo & -5.65308 & 14.3181 & RUN46 & TAG9 & 66,676 & 35.6465 & 38.4587 \\
\hline $\begin{array}{l}\text { Raphlaa } \\
\text { Raphia }\end{array}$ & 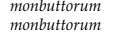 & R059 & Kamdem 211 (WAG) & Cameroon & $\begin{array}{l}3.88505555 \\
3.0675\end{array}$ & $\begin{array}{l}14.39930556 \\
133761\end{array}$ & RUN41 & $\begin{array}{l}\text { TAG9 } \\
\text { TAG78 }\end{array}$ & & $\begin{array}{r}54.2312 \\
208475\end{array}$ & $\begin{array}{l}58.009 \\
254999\end{array}$ \\
\hline $\begin{array}{l}\text { Kappla } \\
\text { Raphia }\end{array}$ & monbuttorum & $\begin{array}{l}\text { Ro6 } \\
\text { R070 }\end{array}$ & $\begin{array}{l}\text { Kamga Mogue 04 (WAG) } \\
\text { Kamga Mogue } 13 \text { (WAG) }\end{array}$ & $\begin{array}{l}\text { Cameroon } \\
\text { Camer }\end{array}$ & $\begin{array}{l}3.068237 \\
3.5823\end{array}$ & $\begin{array}{l}13.56 / 11 \\
13.14197\end{array}$ & $\begin{array}{l}\text { RUN33 } \\
\text { RUNST }\end{array}$ & $\begin{array}{l}\text { TAG/8 } \\
\text { TAG40 }\end{array}$ & $\begin{array}{l}40,023 \\
352731\end{array}$ & 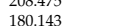 & $\begin{array}{l}2459399 \\
231782\end{array}$ \\
\hline Raphia & monbuttorum & R173 & Kamga Mogue 31 (WAG) & Cameroon & 4.18332 & 13.10538 & RUN41 & TAG46 & 98,860 & 50.8202 & 56.6257 \\
\hline Raphia & $\begin{array}{l}\text { palma-pinus } \\
\text { palurninus }\end{array}$ & R133 & Ouatara \& Stauffer 14 (G) & Ghana & 5.39625 & -1.38277778 & $\begin{array}{l}\text { RUN37 } \\
\text { RUN67 }\end{array}$ & TAG5 & 792,856 & 411.261 & 507.288 \\
\hline $\begin{array}{l}\text { Raphia } \\
\text { Raphia }\end{array}$ & $\begin{array}{l}\text { palmal-pinus } \\
\text { regalis }\end{array}$ & $\begin{array}{l}\text { TC-S1328 } \\
\text { R055 }\end{array}$ & 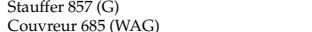 & $\begin{array}{l}\text { Ivory Coast } \\
\text { Comeroon }\end{array}$ & $\begin{array}{l}7.24598 \\
2.4409\end{array}$ & -5.39625 & $\begin{array}{l}\text { RUN67 } \\
\text { RUN33 }\end{array}$ & $\begin{array}{l}\text { TAG-26 } \\
\text { TAG30 }\end{array}$ & $\begin{array}{l}459,813 \\
{ }_{18493}\end{array}$ & $\begin{array}{l}318.875 \\
94999\end{array}$ & $\begin{array}{l}309.014 \\
128098\end{array}$ \\
\hline $\begin{array}{l}\text { Kaphata } \\
\text { Raphia }\end{array}$ & $\begin{array}{l}\text { regalls } \\
\text { regalis }\end{array}$ & $\begin{array}{l}\text { R055 } \\
\text { R056 }\end{array}$ & $\begin{array}{l}\text { Couvrruur 685( WAG) } \\
\text { Couvreur 753 (WAG) }\end{array}$ & $\begin{array}{l}\text { Cameroon } \\
\text { Cameon }\end{array}$ & 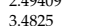 & $\begin{array}{l}10.38444 \\
135969\end{array}$ & RUN33 & Thas & $\begin{array}{l}\begin{array}{l}184,9,93 \\
210,853\end{array} \\
2\end{array}$ & $\begin{array}{l}94.4991 \\
170989\end{array}$ & $\begin{array}{l}128.908 \\
13745\end{array}$ \\
\hline Raphia & $\begin{array}{l}\text { regallis } \\
\text { regals }\end{array}$ & $\begin{array}{l}\mathrm{R} 058 \\
\mathrm{R}\end{array}$ & Couvreur 398 (WAG) & Cameroon & 3.19962 & 10.51772 & RUN33 3 & TAG33 & $\begin{array}{l}21,0,030 \\
388,670\end{array}$ & $\begin{array}{l}106.8907 \\
196.877\end{array}$ & 269.794 \\
\hline Raphia & regalis & R081 & Wieringa 8539 (WAG) & Gabon & -2.37125 & 11.16443 & (1) & TAG46 & 161,079 & 81.8365 & 100.151 \\
\hline $\begin{array}{l}\text { Raphia } \\
\text { Raphia }\end{array}$ & $\begin{array}{l}\text { regalis } \\
\text { rostrtata }\end{array}$ & R083 & $\begin{array}{l}\text { Wieringa } 8547 \text { (WAG) } \\
\text { Kamga Mogue e3 (WAG) }\end{array}$ & $\begin{array}{l}\text { Gabon } \\
\text { Cameron }\end{array}$ & $\begin{array}{l}-2.3714 \\
2.339\end{array}$ & 11.16399 & $\begin{array}{l}\text { RUN33 } \\
\text { RUN67 }\end{array}$ & TAG48 & $\begin{array}{l}150,544 \\
476709\end{array}$ & 76.7195 & 98.4529 \\
\hline $\begin{array}{l}\text { Kaphia } \\
\text { Raphia }\end{array}$ & 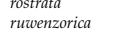 & $\begin{array}{l}\text { R229 } \\
\text { RA_RU }\end{array}$ & 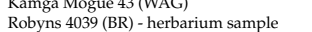 & $\begin{array}{l}\text { Cameroon } \\
\text { Democratic Republic of Congo }\end{array}$ & $\begin{array}{l}2.339 \\
\mathrm{NA}\end{array}$ & $\begin{array}{l}10.6025 \\
\mathrm{NA}\end{array}$ & $\begin{array}{l}\text { RUN67 } \\
\text { P6655 } 10\end{array}$ & $\begin{array}{l}\text { A AG-30 } \\
\text { N/A }\end{array}$ & 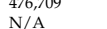 & $\begin{array}{l}329.286 \\
\text { NAA }\end{array}$ & $\begin{array}{l}313.366 \\
\mathrm{~N} / \mathrm{A}\end{array}$ \\
\hline Raphia & sese & R179 & 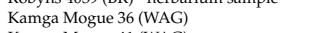 & Democratic Republic of Congo & -5.02068 & 15.1545 & RUN46 & TAG7 & 62972 & 33.7432 & 37.0717 \\
\hline Raphia & sese & R195 & ue 41 (WAG) & Democratic Republic of Congo & -0.8642 & 18.1458 & 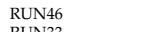 & TAG12 & & 47.5337 & 50.4421 \\
\hline $\begin{array}{l}\text { Raphia } \\
\text { Raphio }\end{array}$ & $\begin{array}{l}\text { suddanica } \\
\text { suldainca }\end{array}$ & $\begin{array}{l}\text { R086 } \\
\text { R129 }\end{array}$ & $\begin{array}{l}\text { Michon 09 (G) } \\
\text { Baytron } 70(\mathrm{~K})\end{array}$ & $\begin{array}{l}\text { Benin } \\
\text { Burkina Faso }\end{array}$ & $\begin{array}{l}7.55826 \\
10593888\end{array}$ & $\begin{array}{l}2.19247 \\
{ }_{5}^{20} 06444\end{array}$ & $\begin{array}{l}\text { RUN333 } \\
\text { RUN37 } 350\end{array}$ & $\begin{array}{l}\text { TAG49 } \\
\text { TAG2 }\end{array}$ & $\begin{array}{l}379,755 \\
470907\end{array}$ & 193.881 & 231.648 \\
\hline Raphia & $\begin{array}{l}\text { suaturat } \\
\text { sulanica }\end{array}$ & R088 & $\begin{array}{l}\text { Machon } 56(\mathrm{G}) \\
\text { Michon }\end{array}$ & $\begin{array}{l}\text { Durkma faso } \\
\text { Togo }\end{array}$ & 8.98317 & $\begin{array}{l}-5.302094444 \\
1.4929\end{array}$ & RUN33 & $\begin{array}{l}\text { TAG52 } \\
\text { TAG5 }\end{array}$ & $\begin{array}{l}47,9599 \\
355,099\end{array}$ & 181.913 & 292.289 \\
\hline Raphia & 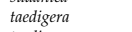 & RA_TA & Noblick 5015 (K) - (herbarium sample) & Brazil & -1.5666 & -48.73333 & AFNBJ_P2059_3047 & $\mathrm{N} / \mathrm{A}$ & $\mathrm{N} / \mathrm{A}$ & N/A & $\mathrm{N} / \mathrm{A}$ \\
\hline Raphia & 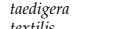 & Env0563 & MBC $94803 \mathrm{~A}$ (MBC) & Cultivated, Montgomery Botanical Garden & N/A & & RUN67 & TAG-22 & 606,580 & 446.883 & 465.14 \\
\hline $\begin{array}{l}\text { Raphia } \\
\text { Raphia }\end{array}$ & $\begin{array}{l}\text { textilis } \\
\text { textilis }\end{array}$ & & $\begin{array}{l}\text { Lautenschlager } 1086 \text { ( }(\mathrm{ACQ}) \\
\text { Kamga a o gue } 40 \text { (WAG) }\end{array}$ & $\begin{array}{l}\text { Angola } \\
\text { Democratic Rep }\end{array}$ & $\begin{array}{l}-6.74019 \\
-088513\end{array}$ & $\begin{array}{l}16.20117 \\
181337\end{array}$ & RUN46 & $\begin{array}{l}\text { TAG19 } \\
-\end{array}$ & $\begin{array}{l}50,163 \\
78383\end{array}$ & 26.882 & $\begin{array}{l}30.0834 \\
4658968\end{array}$ \\
\hline Raphia & $\begin{array}{l}\text { textulls } \\
\text { textilis }\end{array}$ & $\begin{array}{l}\text { R192 } \\
\text { R149 }\end{array}$ & $\begin{array}{l}\text { Kamga Mogue 40 (WAG) } \\
\text { Couvreur } 743 \text { (WAG) }\end{array}$ & $\begin{array}{l}\text { Demomoratc Kepublic of Congo } \\
\text { Gabon }\end{array}$ & $\begin{array}{l}-0.88513 \\
-1.4988\end{array}$ & $\begin{array}{l}18.1 .1357 \\
13.85903\end{array}$ & $\begin{array}{l}\text { RUN46 } \\
\text { RUN41 }\end{array}$ & $\begin{array}{l}\text { IAG11 } \\
\text { TAG29 }\end{array}$ & $\begin{array}{l}78,78 \\
132,014\end{array}$ & $\begin{array}{l}42.04848 \\
68.4236\end{array}$ & $\begin{array}{l}46.2688 \\
80.0799\end{array}$ \\
\hline Raphia & textilis & R151 & Couvreur 10 & Gabon & -1.40695 & 12.5712 & RUN41 & TAG31 & 80,524 & 41.722 & $\begin{array}{l}85.5424 \\
4524\end{array}$ \\
\hline Raphia & vinifera & & Couvreur 638 (WAG) & Cameroon & 6.366476985 & 10.894598 & RUN41 & TAG12 & 87,308 & 455.4189 & 49.1511 \\
\hline $\begin{array}{l}\text { Raphia } \\
\text { Raphia }\end{array}$ & $\begin{array}{l}\text { vinififera } \\
\text { vinfera }\end{array}$ & 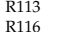 & Couvreur 638 (WAG) & Cameroon & $\begin{array}{l}6.27413 \\
548034\end{array}$ & 10.51091 & $\begin{array}{l}\text { RUN37 } \\
\text { RUN37 }\end{array}$ & $\begin{array}{l}\text { TAG94 } \\
\text { TAC97 }\end{array}$ & 年86,322 & $\begin{array}{l}145.81 \\
189172\end{array}$ & $\begin{array}{l}177.287 \\
20664\end{array}$ \\
\hline $\begin{array}{l}\text { Kaphata } \\
\text { Raphia }\end{array}$ & $\begin{array}{l}\text { vinfera } \\
\text { zamiana }\end{array}$ & $\begin{array}{l}\text { R116 } \\
\text { R057 }\end{array}$ & $\begin{array}{l}\text { Novovocher } \\
\text { Couvreur } 427 \text { (WAG) }\end{array}$ & $\begin{array}{l}\text { Cameroon } \\
\text { Cameroon }\end{array}$ & $\begin{array}{l}5.480344 \\
3.59972\end{array}$ & 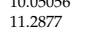 & $\begin{array}{l}\text { RUN37 } \\
\text { RUN33 }\end{array}$ & $\begin{array}{l}\text { IAG97 } \\
\text { TAG32 }\end{array}$ & $\begin{array}{l}36,120 \\
411,897\end{array}$ & $\begin{array}{l}189.9 / 2 \\
209629\end{array}$ & $\begin{array}{l}220.06899 \\
268.899\end{array}$ \\
\hline Raphia & zamiana & $\mathrm{R} 093$ & Ayole 20 (YA) & Cameroon & 3.23685 & 10.02514 & RUN37 & TAG79 & 300,001 & 153.527 & 177.289 \\
\hline Raphia & zamiana & R095 & Ayole 32 (YA) & Cameroon & 2.80897 & $\begin{array}{l}10.52734 \\
0.971397\end{array}$ & $\begin{array}{l}\text { RUN37 } \\
\text { RUNG7 }\end{array}$ & TAG81 & $\begin{array}{l}420,757 \\
46505\end{array}$ & 215.428 28 & 250.534 \\
\hline $\begin{array}{l}\text { Raphraa } \\
\text { Raphia }\end{array}$ & zamiana & & 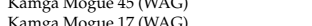 & Cameroon & $\begin{array}{l}3.1376 / 2 \\
3.5982\end{array}$ & 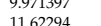 & 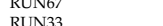 & 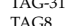 & 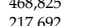 & 318.682 & 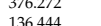 \\
\hline Raphia & $\begin{array}{l}\text { zamanana } \\
\text { zamiana }\end{array}$ & $\begin{array}{l}\text { Roor } \\
\text { Roo9 }\end{array}$ & $\begin{array}{l}\text { Kamga Mogue } 17(\mathrm{WAG}) \\
\text { Kamga Mogue } 17 \text { (WAG) }\end{array}$ & $\begin{array}{l}\text { Gabon } \\
\text { Gabon }\end{array}$ & $\begin{array}{l}1.59848 \\
-2.25428\end{array}$ & 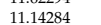 & RUN33 & TAG10 & 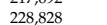 & 116.278 & $\begin{array}{l}136.444 \\
144.853\end{array}$ \\
\hline Raphia & zamiana & R154 & Couvreur 1122 (WAG) & Gabon & -0.1473 & 11.726 & RUN41 & TAG33 & 56,712 & 29.1983 & 31.1171 \\
\hline
\end{tabular}




\section{Appendix B}

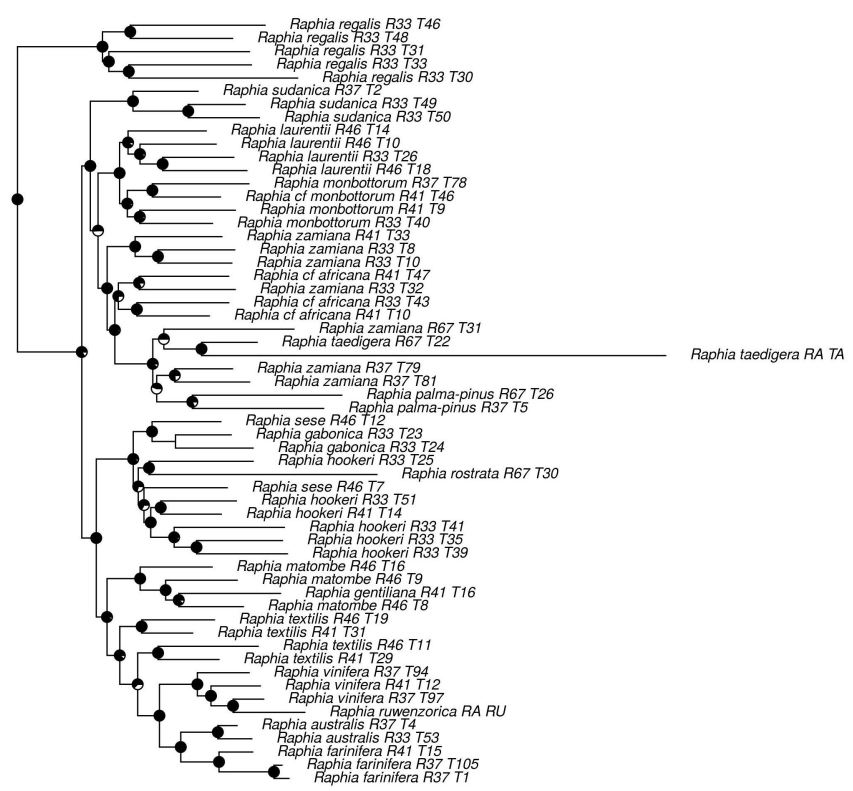

Figure A1. IQTREE Raphia inferred using $162 \mathrm{~kb}$ of sequence data. Values for ultrafast bootstrap support are depicted on nodes.

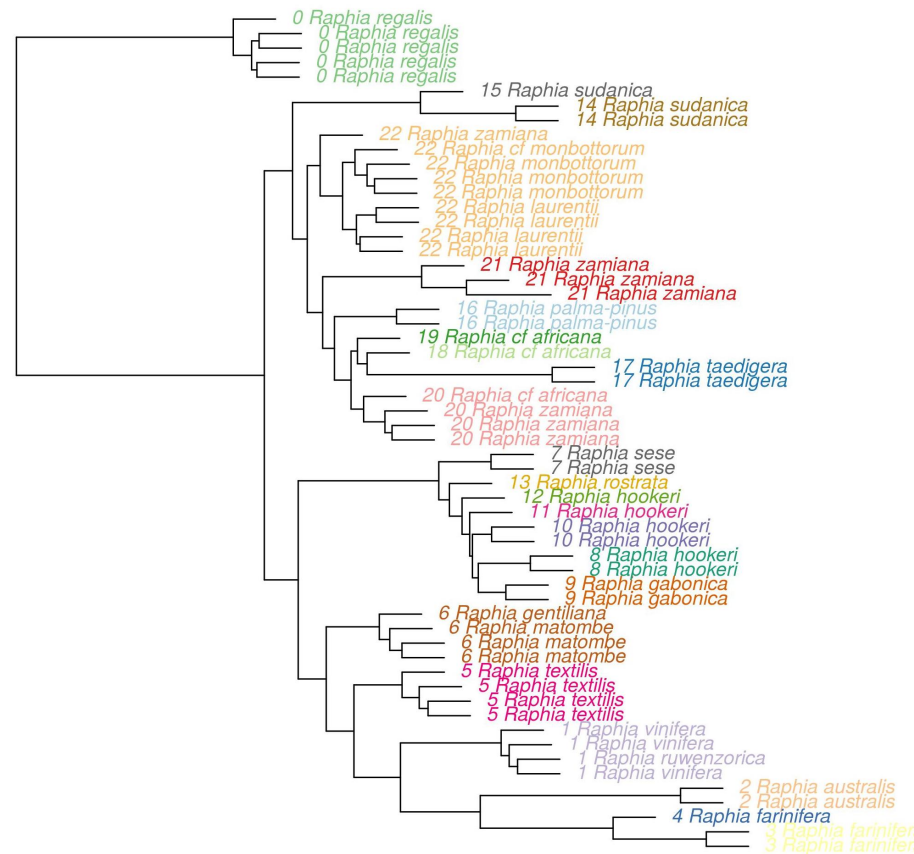

Figure A2. ASTRAL tree of Raphia including inferred branch lengths (except terminal branch lengths) and tip labels colored with species delimitation as inferred with SODA $(\alpha=0.01)$.

\section{References}

1. Dransfield, J.; Uhl, N.W.; Asmussen, C.B.; Baker, W.J.; Harley, M.M.; Lewis, C.E. Genera Palmarum: The Evolution and Classification of Palms; Kew Publishing: Kew, UK, 2008.

2. Stauffer, F.W.; Ouattara, D.N.; Roguet, D.; da Giau, S.; Michon, L.; Bakayoko, A.; Ekpe, P. An update to the African palms (Arecaceae) floristic and taxonomic knowledge, with emphasis on the West African region. Webbia 2017, 72, 1-14. [CrossRef] 
3. Cosiaux, A.; Gardiner, L.M.; Stauffer, F.W.; Bachman, S.P.; Sonké, B.; Baker, W.J.; Couvreur, T.L.P. Low extinction risk for an important plant resource: Conservation assessments of continental African palms (Arecaceae/Palmae). Biol. Conserv. 2018, 221, 323-333. [CrossRef]

4. Moore, H.E. Palms in the tropical forest ecosystems of Africa and South America. In Tropical Forest Ecosystems of Africa and South America: A Comparative Review; Meggers, B.J., Ayensu, E., Duckworth, W.D., Eds.; Smithsonian Institution Press: Washintong, DC, USA, 1973; pp. 63-88.

5. Couvreur, T.L.P. Odd man out: Why are there fewer plant species in African rain forests? Plant Syst. Evol. 2015, 301, 1299-1313. [CrossRef]

6. Dransfield, J. The palms of Africa and their relationships. In Modern Systematic Studies in African Botany; Goldblatt, P., Lowry, P.P., Eds.; Missouri Botanical Garden Press: St. Louis, MO, USA, 1988; pp. 95-103.

7. Mogue Kamga, S.; Niangadouma, R.; Stauffer, F.W.; Sonké, B.; Couvreur, T.L.P. Two new species of Raphia (Palmae/Arecaceae) from Cameroon and Gabon. PhytoKeys 2018, 111, 17-30. [CrossRef] [PubMed]

8. Urquhart, G.R. Long-term Persistence of Raphia taedigera Mart. Swamps in Nicaragua1. Biotropica 1999, 31, 565-569. [CrossRef]

9. Urquhart, G.R. Paleoecological evidence of Raphia in the Pre-Columbian Neotropics. J. Trop. Ecol. 1997, 13, 783-792. [CrossRef]

10. Otedoh, M.O. Systematic Studies in Raphia Palms. Ph.D. Thesis, University of Reading, Reading, UK, 1976.

11. Otedoh, M.O. The African origin of Raphia taedigera-Palmae. J. Niger. Inst. Oil Palm Res 1977, 42, 11-16.

12. Mogue Kamga, S.; Brokamp, G.; Cosiaux, A.; Awono, A.; Fürniss, S.; Barfod, A.S.; Muafor, F.J.; Le Gall, P.; Sonké, B.; Couvreur, T.L.P. Use and cultural significance of Raphia palms. Econ. Botany 2020, 74, in press. [CrossRef]

13. Lautenschläger, T.; Neinhuis, C., Eds. Riquezas Naturais de Uíge-Uma Breve Introdução sobre o Estado Atual, a Utilização, a Ameaça e a Preservação da Biodiversidade; Technische Universität Dresden: Dresden, Germany, 2014. [CrossRef]

14. Obahiagbon, F.I. A review of the origin, morphology, cultivation, economic products, health and physiological implications of raphia palm. Afr. J. Food Sci. 2009, 3, 447-453.

15. Couvreur, T.L.P.; Fumtim, J. A l'Echelle du Raphia/On Raphia and Man. 2017. Available online: https: / / www.youtube.com/watch?v=avSoLIusCCs\&t=1167s (accessed on 8 April 2020).

16. Profizi, J.P. Swampy Area Transformations by Exploitation of Raphia hookeri (Arecaceae) in Southern Benin (West Africa). Hum. Ecol. 1988, 16, 87-94.

17. Dargie, G.C.; Lewis, S.L.; Lawson, I.T.; Mitchard, E.T.A.; Page, S.E.; Bocko, Y.E.; Ifo, S.A. Age, extent and carbon storage of the central Congo Basin peatland complex. Nature 2017, 542, 86-90. [CrossRef]

18. Rainey, H.J.; Iyenguet, F.C.; Malanda, G.A.F.; Madzoké, B.; Santos, D.D.; Stokes, E.J.; Maisels, F.; Strindberg, S. Survey of Raphia swamp forest, Republic of Congo, indicates high densities of Critically Endangered western lowland gorillas Gorilla gorilla gorilla. Oryx 2010, 44, 124-132. [CrossRef]

19. Couvreur, T.L.P.; Helmstetter, A.J.; Koenen, E.J.M.; Bethune, K.; Brandão, R.D.; Little, S.A.; Sauquet, H.; Erkens, R.H.J. Phylogenomics of the Major Tropical Plant Family Annonaceae Using Targeted Enrichment of Nuclear Genes. Front. Plant Sci. 2019, 9, 1941. [CrossRef] [PubMed]

20. Tuley, P. The palms of Africa; The Tendrine Press: Zennor, UK, 1995. [CrossRef]

21. Otedoh, M.O. A revision of the genus Raphia Beauv. (Palmae). J. Niger. Inst. Oil Palm Res 1982, 6, 145-189. [CrossRef] [PubMed]

22. Beccari, O. Studio monografico del genere "Raphia“. Webbia 1910, 3, 37-130. [CrossRef] [PubMed]

23. Russell, T.A. The Raphia Palms of West Africa. Kew Bulletin 1965, 19, 173-196. [CrossRef]

24. Tuley, P.; Russell, T.A. The Raphia palms reviewed. Nigerian Field 1966, 31, 54-65.

25. Baker, W.J.; Dransfield, J.; Hedderson, T.A. Phylogeny, character evolution, and a new classification of the calamoid palms. Syst. Botany 2000, 25, 297-322. [CrossRef]

26. Heyduk, K.; Trapnell, D.W.; Barrett, C.F.; Leebens-Mack, J. Phylogenomic analyses of species relationships in the genus Sabal (Arecaceae) using targeted sequence capture. Biol. J. Linn. Soc. 2016, 117, 106-120. [CrossRef]

27. Ouattara, D.N.; Stauffer, F.W.; Bakayoko, A. Lectotypification de Raphia sudanica A. Chev. (Arecaceae, Calamoideae), et commentaires sur la biologie et la conservation de l'espèce. Adansonia 2014, 36, $53-61$.

28. Liu, X.; Fu, Y.X. Exploring population size changes using SNP frequency spectra. Nat. Gen. 2015, 47, 555-559. [CrossRef] 
29. Tonini, J.; Moore, A.; Stern, D.; Shcheglovitova, M.; Ortí, G. Concatenation and Species Tree Methods Exhibit Statistically Indistinguishable Accuracy under a Range of Simulated Conditions. PLoS Curr. 2015, 7. [CrossRef]

30. Springer, M.S.; Gatesy, J. The gene tree delusion. Mol. Phylogen. Evol. 2016, 94, 1-33, [CrossRef]

31. Zhang, C.; Sayyari, E.; Mirarab, S. ASTRAL-III: Increased scalability and impacts of contracting low support branches. In Lecture Notes in Computer Science; including subseries Lecture Notes in Artificial Intelligence and Lecture Notes in Bioinformatics; Springer: Berlin, Germany, 2017; Volume 10562, pp. 53-75, [CrossRef] [PubMed]

32. Mogue Kamga, S.; Sonké, B.; Couvreur, T.L.P. Raphia vinifera (Arecaceae; Calamoideae): Misidentified for far too long. Biodiver. Data J. 2019, 7, e37757. [CrossRef] [PubMed]

33. Robyns, W.; Tournay, R. Monocotylées nouvelles ou critiques de la région du Parc National Albert (Congo belge). Bulletin du Jardin botanique de l'État a Bruxelles 1955, 25, 239-260, [CrossRef] [PubMed]

34. Stauffer, F.W.; Ouattara, D.; Stork, A.L. Palmae. In Tropical African Flowering Plants: Monocotyledons 2; Lebrun, J.P., Stork, A.L., Eds.; Conservatoire et Jardin botaniques de la Ville de Genève: Geneva, Switzerland, 2014; Volume 8, pp. 326-354. [CrossRef]

35. Couvreur, T.L.P. Monograph of the syncarpous African genera Isolona and Monodora (Annonaceae). Syst. Botany Monogr. 2009, 87, 1-150. [CrossRef]

36. Kadu, C.A.C.; Schueler, S.; Konrad, H.; Muluvi, G.M.M.; Eyog-Matig, O.; Muchugi, A.; Williams, V.L.; Ramamonjisoa, L.; Kapinga, C.; Foahom, B.; et al. Phylogeography of the Afromontane Prunus africana reveals a former migration corridor between East and West African highlands. Mol. Ecol. 2011, 20, 165-178. [CrossRef]

37. Dale, I.R. Palms of Kenya. J. East Afr. Uganda Nat. Hist. Society 1938, 23, 183-186.

38. Russell, T.A. Palmae. In Flora of West Tropical Africa, 2 ed.; Hutchinson, J., Dalziel, J.M., Hepper, F., Eds.; Crown Agents for Oversea Governments and Administrations: London, UK, 1968; Volume 3; pp. 159-169.

39. Dransfield, J. Palmae. In Flora of Tropical East Africa; Polhill, R., Ed.; A.A. Balkema: Rotterdam, The Netherlands, 1986; pp. 1-58. [CrossRef]

40. Dransfield, J.; Beentje, H.J. The palms of Madagascar; Royal Botanic Gardens and International Palm Society: Kew, UK, 1995.

41. Baker, W.J.; Smith, G.F. Palmae. In Plants of Angola; Number 23 in Strelitzia; Figueiredo, E., Ed.; South African National Biodiversity Institute (SANBI): Pretoria, South Africa, 2008; pp. 172-173.

42. Faye, A.; Moutsamboté, J.; Couvreur, T.L.P. Palms in southern Republic of Congo. PALMS 2016, 59, 181-190.

43. Dransfield, J.; Rakotoarinivo, M. The biogeography of Madagascar palms. In The Biology of Island Floras; Bramwell, D., Caujapé-Castells, J., Eds.; Cambridge University Press: Cambridge, UK, 2011; pp. 179-196.

44. Jumelle, H.; Perrier de la Bathié, M. Palmiers. In Flore de Madagascar et des Comores (Plantes Vasculaires); Humbert, H., Ed.; Impr. Officielle. Tananarive: Tananarive, Madagascar, 1945; Volume 30, pp. 1-185.

45. Mann, G.; Wendland, H.A. On the Palms of Western Tropical Africa. Trans. Linn. Soc. Lond. 1864, 24, 421-440. [CrossRef]

46. Hardy, O.J.; Born, C.; Budde, K.; Daïnou, K.; Dauby, G.; Duminil, J.Ô.; Ewédjé, E.E.B.; Gomez, C.; Heuertz, M.; Koffi, G.K.; et al. Comparative phylogeography of African rain forest trees: A review of genetic signatures of vegetation history in the Guineo-Congolian region. Comptes Rendus Geosci. 2013, 345, 284-296. [CrossRef]

47. Helmstetter, A.J.; Amoussou, B.E.N.; Bethune, K.; Kamdem, N.G.; Kakaï, R.G.; Sonké, B.; Couvreur, T.L.P. Phylogenomic data reveal how a climatic inversion and glacial refugia shape patterns of diversity in an African rain forest tree species. bioRxiv 2019. [CrossRef]

48. Baker, W.J.; Savolainen, V.; Asmussen-Lange, C.B.; Chase, M.W.; Dransfield, J.; Forest, F.; Harley, M.M.; Uhl, N.W.; Wilkinson, M. Complete generic-level phylogenetic analyses of palms (Arecaceae) with comparisons of supertree and supermatrix approaches. Syst. Biol. 2009, 58, 240-256. [CrossRef]

49. Rohland, N.; Reich, D. Cost-effective, high-throughput DNA sequencing libraries for multiplexed target capture. Gen. Res. 2012, 22, 939-946. [CrossRef]

50. Johnson, M.G.; Gardner, E.M.; Liu, Y.; Medina, R.; Goffinet, B.; Shaw, A.J.; Zerega, N.J.C.; Wickett, N.J. HybPiper: Extracting Coding Sequence and Introns for Phylogenetics from High-Throughput Sequencing Reads Using Target Enrichment. Appl. Plant Sci. 2016, 4, 1600016. [CrossRef]

51. Katoh, K.; Standley, D.M. MAFFT multiple sequence alignment software version 7: Improvements in performance and usability. Mol. Biol. Evol. 2013, 30, 772-780. [CrossRef] 
52. Castresana, J. Selection of conserved blocks from multiple alignments for their use in phylogenetic analysis. Mol. Biol. Evol. 2000, 17, 540-552. [CrossRef] [PubMed]

53. Sayyari, E.; Mirarab, S. Fast Coalescent-Based Computation of Local Branch Support from Quartet Frequencies. Mol. Biol. Evol. 2016, 33, 1654-1668. [CrossRef] [PubMed]

54. Stamatakis, A. RAxML version 8: A tool for phylogenetic analysis and post-analysis of large phylogenies. Bioinformatics 2014, 30, 1312-1313. [CrossRef]

55. Junier, T.; Zdobnov, E.M. The Newick utilities: High-throughput phylogenetic tree processing in the UNIX shell. Bioinformatics 2010, 26, 1669-1670. [CrossRef]

56. Rabiee, M.; Mirarab, S. SODA: Multi-locus species delimitation using quartet frequencies. bioRxiv 2019. [CrossRef]

57. Yang, Z. The BPP program for species tree estimation and species delimitation. Curr. Zool. 2015, 61, 854-865. [CrossRef]

58. Brown, J.W.; Walker, J.F.; Smith, S.A. Phyx: Phylogenetic tools for unix. Bioinformatics 2017, 33, 1886-1888. [CrossRef]

59. Nguyen, L.T.; Schmidt, H.A.; Von Haeseler, A.; Minh, B.Q. IQ-TREE: A fast and effective stochastic algorithm for estimating maximum-likelihood phylogenies. Mol. Biol. Evol. 2015, 32, 268-274. [CrossRef]

60. Kalyaanamoorthy, S.; Minh, B.Q.; Wong, T.K.; Von Haeseler, A.; Jermiin, L.S. ModelFinder: Fast model selection for accurate phylogenetic estimates. Nat. Meth. 2017, 14, 587-589. [CrossRef]

61. Lanfear, R.; Calcott, B.; Kainer, D.; Mayer, C.; Stamatakis, A. Selecting optimal partitioning schemes for phylogenomic datasets. BMC Evol. Biol. 2014, 14, 82. [CrossRef]

62. Hoang, D.T.; Chernomor, O.; Von Haeseler, A.; Minh, B.Q.; Vinh, L.S. UFBoot2: Improving the ultrafast bootstrap approximation. Mol. Biol. Evol. 2018, 35, 518-522. [CrossRef]

63. Guindon, S.; Dufayard, J.F.; Lefort, V.; Anisimova, M.; Hordijk, W.; Gascuel, O. New algorithms and methods to estimate maximum-likelihood phylogenies: Assessing the performance of PhyML 3.0. Syst. Biol. 2010, 59, 307-321. [CrossRef] [PubMed]

64. Andermann, T.; Cano, Á.; Zizka, A.; Bacon, C.; Antonelli, A. SECAPR-A bioinformatics pipeline for the rapid and user-friendly processing of targeted enriched Illumina sequences, from raw reads to alignments. PeerJ 2018, 6, e5175. [CrossRef]

65. Li, H.; Durbin, R. Fast and accurate short read alignment with Burrows-Wheeler transform. Bioinformatics 2009, 25, 1754-1760. [CrossRef] [PubMed]

66. McKenna, A.; Hanna, M.; Banks, E.; Sivachenko, A.; Cibulskis, K.; Kernytsky, A.; Garimella, K.; Altshuler, D.; Gabriel, S.; Daly, M.; et al. The Genome Analysis Toolkit: A MapReduce framework for analyzing next-generation DNA sequencing data. Gen. Res. 2010, 20, 1297-303. [CrossRef] [PubMed]

67. Li, H.; Barrett, J. A statistical framework for SNP calling, mutation discovery, association mapping and population genetical parameter estimation from sequencing data. Bioinformatics 2011, 27, 2987-2993. [CrossRef]

68. Jombart, T.; Devillard, S.; Balloux, F. Discriminant analysis of principal components: A new method for the analysis of genetically structured populations. BMC Gen. 2010, 11, 94. [CrossRef]

69. Jombart, T. Adegenet: A R package for the multivariate analysis of genetic markers. Bioinformatics 2008, 24, 1403-1405. [CrossRef]

70. Lissambou, B.J.; Couvreur, T.L.P.; Atteke, C.; Stévart, T.; Piñeiro, R.; Dauby, G.; Monthe, F.K.; Ikabanga, D.U.; Sonké, B.; M'batchi, B.; Hardy, O.J. Species delimitation in the genus Greenwayodendron based on morphological and genetic markers reveals new species. TAXON 2019, 68, 442-454. [CrossRef]

71. Monthe, F.K.; Duminil, J.; Kasongo Yakusu, E.; Beeckman, H.; Bourland, N.; Doucet, J.L.; Sosef, M.S.M.; Hardy, O.J. The African timber tree Entandrophragma congoense (Pierre ex De Wild.) A. Chev. is morphologically and genetically distinct from Entandrophragma angolense (Welw.) C.DC. Tree Gen. Gen. 2018, 14, 66. [CrossRef]

72. Daïnou, K.; Blanc-Jolivet, C.; Degen, B.; Kimani, P.; Ndiade-Bourobou, D.; Donkpegan, A.S.L.; Tosso, F.; Kaymak, E.; Bourland, N.; Doucet, J.L.; et al. Revealing hidden species diversity in closely related species using nuclear SNPs, SSRs and DNA sequences - a case study in the tree genus Milicia. BMC Evol. Biol. 2016, 16, 259. [CrossRef] [PubMed]

73. Melo, W.A.; Freitas, C.G.; Bacon, C.D.; Collevatti, R.G. The road to evolutionary success: Insights from the demographic history of an Amazonian palm. Heredity 2018, 121, 183-195. [CrossRef] [PubMed] 
74. Loiseau, O.; Olivares, I.; Paris, M.; de La Harpe, M.; Weigand, A.; Koubínová, D.; Rolland, J.; Bacon, C.D.; Balslev, H.; Borchsenius, F.; et al. Targeted Capture of Hundreds of Nuclear Genes Unravels Phylogenetic Relationships of the Diverse Neotropical Palm Tribe Geonomateae. Front. Plant Sci. 2019, 10. [CrossRef] [PubMed]

(c)

(C) 2020 by the authors. Licensee MDPI, Basel, Switzerland. This article is an open access article distributed under the terms and conditions of the Creative Commons Attribution (CC BY) license (http://creativecommons.org/licenses/by/4.0/). 